San Jose State University

SJSU ScholarWorks

Master's Theses

Master's Theses and Graduate Research

Summer 2021

\title{
Distribution and Habitat Use of the Santa Clara County Population of Red-bellied Newts (Taricha rivularis)
}

Joie de Leon

San Jose State University

Follow this and additional works at: https://scholarworks.sjsu.edu/etd_theses

\section{Recommended Citation}

de Leon, Joie, "Distribution and Habitat Use of the Santa Clara County Population of Red-bellied Newts (Taricha rivularis)" (2021). Master's Theses. 5197.

DOI: https://doi.org/10.31979/etd.3e7b-8dak

https://scholarworks.sjsu.edu/etd_theses/5197

This Thesis is brought to you for free and open access by the Master's Theses and Graduate Research at SJSU ScholarWorks. It has been accepted for inclusion in Master's Theses by an authorized administrator of SJSU ScholarWorks. For more information, please contact scholarworks@sjsu.edu. 


\title{
DISTRIBUTION AND HABITAT USE OF THE SANTA CLARA COUNTY POPULATION OF RED-BELLIED NEWTS (TARICHA RIVULARIS)
}

\author{
A Thesis \\ Presented to \\ The Faculty of the Department of Environmental Studies \\ San José State University
}

\author{
In Partial Fulfillment \\ of the Requirements for the Degree \\ Master of Science
}

by

Joie de Leon

August 2021 
(C) 2021

Joie de Leon

ALL RIGHTS RESERVED 
The Designated Thesis Committee Approves the Thesis Titled

DISTRIBUTION AND HABITAT USE OF THE SANTA CLARA COUNTY POPULATION OF RED-BELLIED NEWTS (TARICHA RIVULARIS)

by

Joie de Leon

APPROVED FOR THE DEPARTMENT OF ENVIRONMENTAL STUDIES

SAN JOSÉ STATE UNIVERSITY

August 2021

Rachel O’Malley, Ph.D

Lynne Trulio, Ph.D

Marvalee H. Wake, Ph.D
Department of Environmental Studies

Department of Environmental Studies

Department of Integrative Biology, University of California, Berkeley 


\section{ABSTRACT \\ DISTRIBUTION AND HABITAT USE OF THE SANTA CLARA COUNTY POPULATION OF RED-BELLIED NEWTS (TARICHA RIVULARIS)}

by Joie de Leon

Anthropogenically-induced habitat loss and degradation have increased extinction rates in amphibians worldwide, yet little is known about many remaining populations. A disjunct population of Red-bellied Newt (Taricha rivularis), an endemic California species, was discovered $130 \mathrm{~km}$ south of its previously known range. Here I document the range and breeding phenology of this population and contrast its mesohabitat use with that of other sympatric newts. Surveys across two years suggest that the southern population of $T$. rivularis is confined to a $1 \mathrm{~km}$ segment of Stevens Creek, and the population follows an early-March to late-April migratory breeding pattern, similar to one documented northern population. Spatial analysis shows that T. rivularis aggregates only in Stevens Creek, likely dispersing through Twitty Creek. Breeding male $T$. rivularis are more associated with riffle and run mesohabitats when compared to pools, while $T$. granulosa and T. torosa tend to be more associated with woody debris cover types and cobble substrates. Female T. rivularis oviposition site selection is most influenced by large substrate size. The protection of large substrate and complex instream habitat in sensitive breeding reaches, as well as upland habitat along dispersal routes, should be an important consideration for land managers. Understanding the nuances of range, temporal behavior, and habitat needs for this disjunct population is critical to ensure the survival of this California Species of Special Concern. 


\section{ACKNOWLEDGMENTS}

First, it is important to acknowledge that the lands on which this research was conducted have been stewarded by the Muwekma, Ohlone, Ramaytush, and Tamien people throughout the generations.

I would like to thank the multiple agencies that were involved in this research conducted: California Department of Fish and Wildlife, Midpeninsula Regional Open Space District and Santa Clara County Parks for permitting, San Jose State University Institutional Animal Care and Use Committee members and staff for ensuring the proper care of these wonderful creatures that we study. I also thank the Environmental Studies Department professors, staff, and students for the memorable experience I have had in the department.

Thank you to Rachel O’Malley for her constant encouragement, wisdom, and guidance even though I was probably very difficult at times. To Marvalee Wake, I am immensely grateful for your last-minute help and encouragement. To all my professors and mentors, I have had over the years, thank you for instilling in me a deep appreciation for ecology and wildlife. I am especially grateful to my mentors Jerry Smith, Nina Merrill, Jae Abel, and Karen Swaim.

To Jen Jelincic, Jessica Gonzalez, Rachael Burnham, and Mary Yan, thank you all for commiserating with me, celebrating my wins with me (no matter how small), and pushing me to complete this journey. To all those that braved the wilderness' San Jose, Palo Alto, and San Mateo Counties to traipse through creeks, climb over logjams, eat mouthfuls of spiderwebs and insects, and risk life and limb with me, I could not have 
done any of this without you.

I must thank two people who started this journey with me but did not see me cross this finish line. To David Wake, thank you for guidance and insightful conversations on the red-bellied newt. I am lucky to have worked with you even if it was only for a short while. And to my friend and mentor, Neil Keung, I wouldn't be where I am today without you. I can only hope to follow your lead in practicing sound science without compromise.

Finally, I thank my parents for their love and support in watching me learn about and chase after wildlife. To my partner in crime since the age of 19, Sovisit, thank you for your love, support, and encouragement as I strived toward my goals no matter how long it takes. 


\section{TABLE OF CONTENTS}

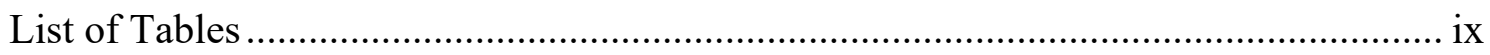

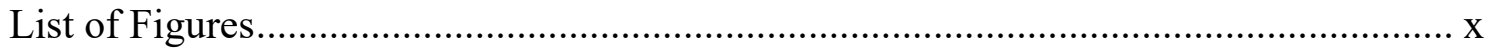

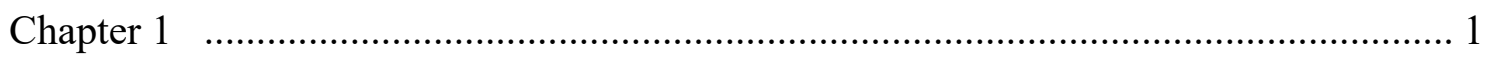

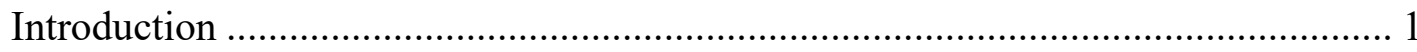

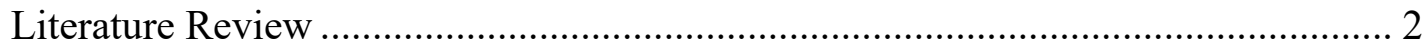

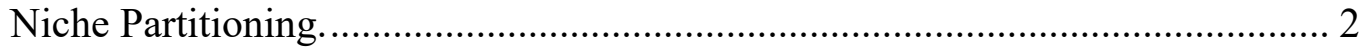

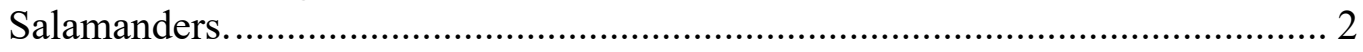

Importance of Salamanders. ........................................................................ 3

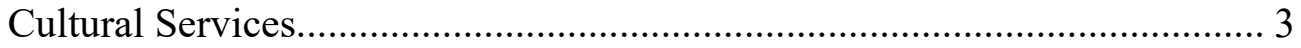

Provisioning Services …………………................................................. 4

Supporting Services.................................................................................. 4

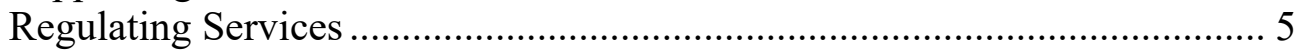

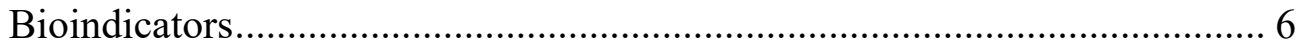

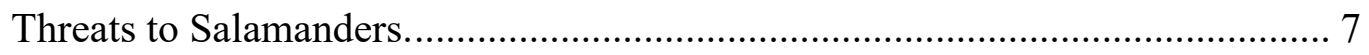

Climate Change ……………………................................................ 7

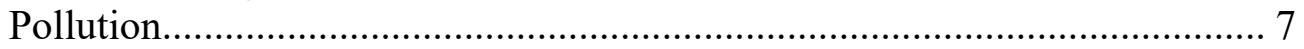

Urbanization and Roads............................................................................ 8

Habitat Loss and Degradation .................................................................. 9

Introduced Exotic Species and Disease ................................................... 10

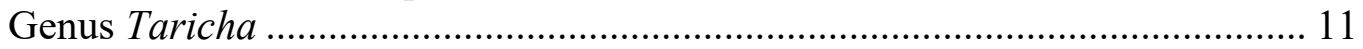

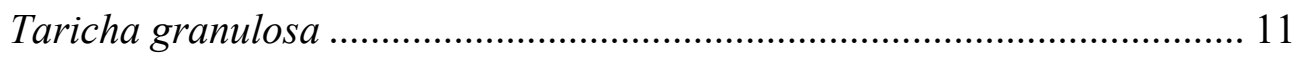

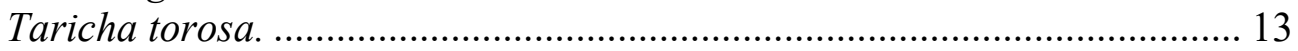

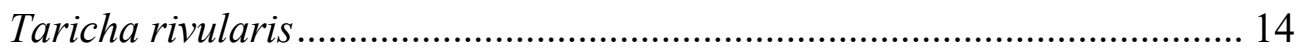

Objectives and Research Questions.................................................................. 18

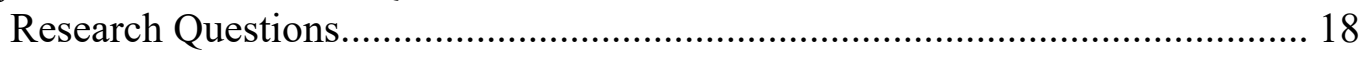

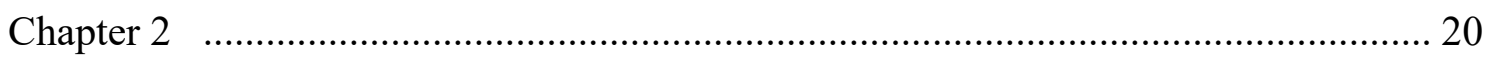

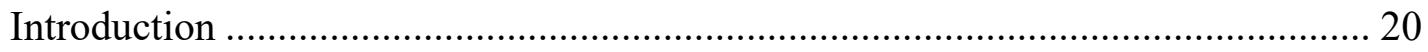

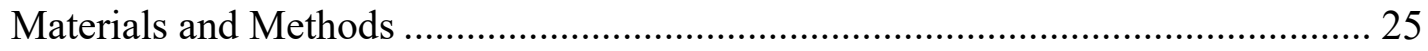

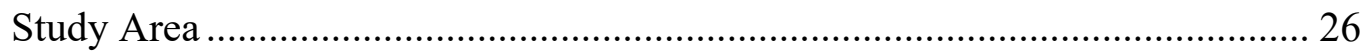

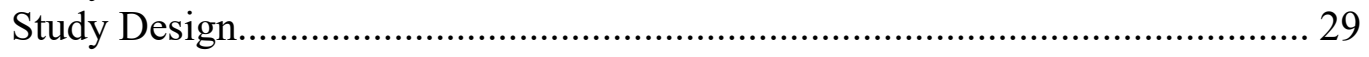

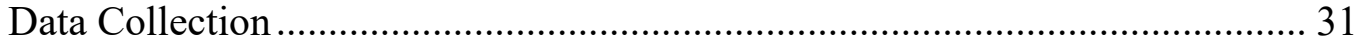

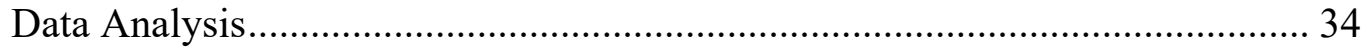

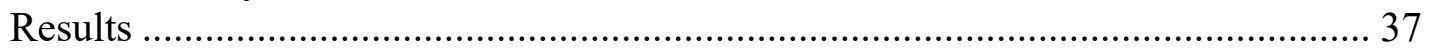

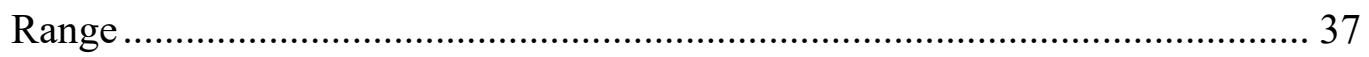

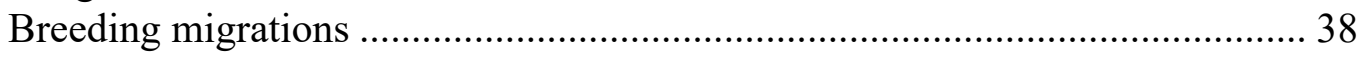

Breeding aggregation.............................................................................. 39 
Habitat use and availability ........................................................................ 40

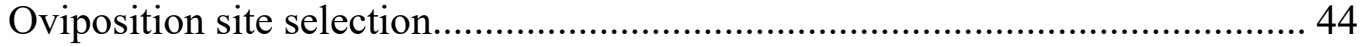

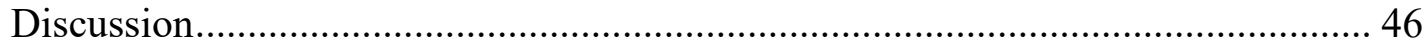

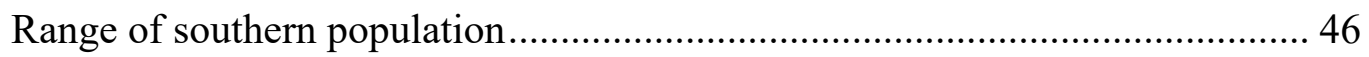

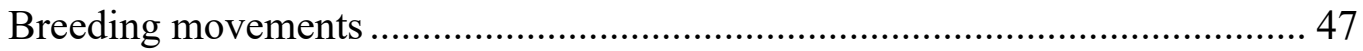

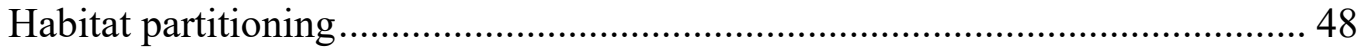

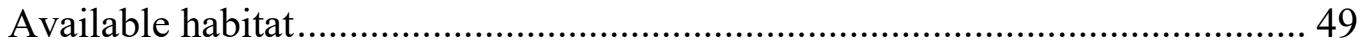

Twitty Creek or Stevens Creek........................................................................ 50

Adult male habitat use .............................................................................. 50

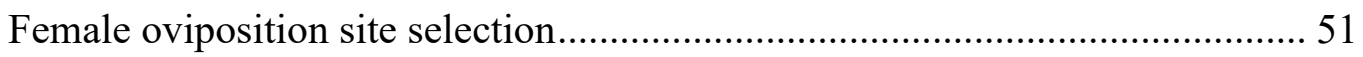

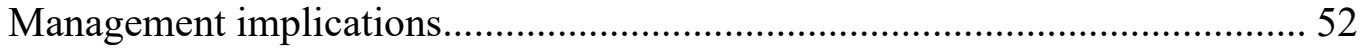

Threats to the southern population of $T$. rivularis ......................................... 53

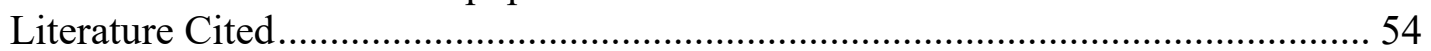




\section{LIST OF TABLES}

Table 1. T. rivularis observations of 2018 in each of the survey locations .............38

Table 2. Count data for each species observed during each survey date in $2019 \ldots 39$

Table 3. Average Nearest Neighbor analysis. $\mathrm{P}>0.05$ : accept the Null $=$ random distribution; $\mathrm{P}<0.05$ : reject null and use the Nearest Neighbor Ratio to determine if distribution is dispersed $(\mathrm{NNR}>1.0)$ or clustered/aggregated (NNR $<1.0)$

Table 4. Count of mesohabitat use by each species encountered.

Table 5. Binary logistic regression results for habitat use. Reference categories mesohabitat: pool, substrate: boulder, and cover type: interstitial spaces. Abbreviations are $\beta=$ coefficient, $S E=$ Standard Error, $Z=$ the Wald's Test statistic (standard deviations), $\mathrm{OR}=$ odds ratio or the exponent of $\beta, C I=$ confidence interval with upper and lower limits. The $(+)$ denotes a positive association with T. rivularis and (-) denotes negative association with $\mathrm{T}$. rivularis............................................. 44

Table 6. Oviposition site characteristics and measurements. ............................. 45

Table 7. Binary logistic regression results for oviposition site selection. .45 


\section{LIST OF FIGURES}

Figure 1. $\quad$ Ranges of T. rivularis, T. granulosa (diagonal lines), and T. torosa (hatched and lines) locations where ranges overlap. The entirety of $T$. rivularis range is shared with $T$. granulosa (light gray).

Figure 2. Map of T. rivularis range around the San Francisco Bay Area in gray. The red dot represents our study site in the Stevens Creek watershed in Santa Clara County.

Figure 3. Study design. .30

Figure 4. Oviposition site substrate size in comparison to paired random unoccupied sites. 


\section{ChAPTER 1}

\section{INTRODUCTION}

One-third of all vertebrate species reside in the freshwater aquatic habitats that cover only $0.8 \%$ of the Earth's surface (Schneider et al. 2011). Among vertebrates, $41 \%$ of the $\sim 8,300$ identified amphibian species are threatened with extinction (IUCN 2021) The major threats to amphibian biodiversity decline are anthropogenic.

Amphibian species, including salamanders (Amphibia: Caudata), play critical ecological roles in their ecosystems (Davic and Welsh 2004). Salamanders provide ecosystem services that benefit their ecosystems and human society (Dudgeon et al. 2006). These services include pest regulation, indirectly supporting other species, and supporting medical research with unique adaptations (Hocking and Babbitt 2014). Salamanders also serve as "harbingers of environmental decay" or bioindicators (Vitt et al. 1990).

As amphibians, salamanders are among the most threatened group of vertebrates in the world (Alford and Richards 1999, IUCN 2021). Threats to salamanders are largely anthropogenic: global climate change, pollution, urbanization, habitat loss, and habitat degradation, introduced exotic species and disease (Alford and Richards 1999; Lannoo 2005; Dudgeon et al. 2006). Climate largely affects species distribution and potentially niche differentiation between closely related species (Corn 2005; Sutton et al. 2015)

The Red-bellied Newt (Taricha rivularis), a highly-specialized salamander species, is particularly vulnerable to habitat loss and fragmentation. Despite its status as a California Priority 2 Species of Special Concern, $T$. rivularis is poorly understood. In 
2009, a single population of T. rivularis was discovered in the Santa Cruz Mountain Range in Santa Clara County. Data on this population could provide insights on how to protect the species throughout its range.

\section{LITERATURE REVIEW}

Niche Partitioning.-The competitive exclusion principle is the concept that if two species share the same niche or ecological role, then one of those species will drive the other to extinction. Conversely, when the two sympatric species occupy different niches, they are less likely to compete and can successfully co-exist (Hardin 1960). Niches can be partitioned differently depending on the ecological difference (food source, macrohabitat requirements, micro-habitat requirements, temporal requirement, etc.) of competing species (Schoener 1974). Recent studies have investigated the expected changes in niche partitioning of species in ecosystems that are most affected by global climate change (Corn 2005; Sutton et al. 2015).

Salamanders._Amphibians are ectotherms comprising three orders of over 8,300 described species. Caecilians (order Gymnophiona), which make up 3\% of described amphibian species, are specialized for burrowing, with no legs, reduced eyes, and an elongated body with grooves (Duellman and Treub 1994; IUCN 2021). Frogs (order Anura) make up $88 \%$ of described amphibian species, with elongated hind legs for jumping and no tails. Salamanders (order Caudata) make up 9\% of described amphibian species, with elongated tails and four limbs of generally the same size (Duellman and Treub 1994; IUCN 2021). Salamanders are among the least understood amphibians due to their cryptic habits and nocturnal nature (Petranka 2010). 
Salamanders exhibit a variety of life histories that are either fully aquatic, fully terrestrial, or biphasic. Biphasic species undergo metamorphosis from an aquatic larva to a terrestrial or semiaquatic adult (Brown and Cai 2007; Dodd 2010; Duellman and Treub 1994). For all salamanders, unprotected gel-like eggs are deposited in locations with high humidity or moisture. Once hatched, salamander larvae with biphasic life histories grow until they metamorphose into juvenile salamanders (Duellman and Treub 1994). Unprotected egg masses and semi-permeable skin, combined with complex life histories, make many salamanders sensitive to changes in environmental conditions and ecological stress (Welsh and Ollivier 1998; Dudgeon et al. 2006).

Importance of Salamanders. - Most amphibian research has been conducted on the more abundant and obvious frog and toad species, which can be quite vocal. Salamanders are a quiet and cryptic group of amphibians that often lives underground between breeding seasons, making research difficult.

Ecosystem services are sometimes categorized into four groups: cultural services (education, recreation, therapeutic), provisioning services (raw materials, genetic resources, energy, food, medicinal resources), supporting services (primary production, soil production, nutrient cycling), and regulating services (pest control, waste decomposition, air, water purification) (Costanza et al. 1997). Salamanders provide ecosystem services that fall into each of these categories

Cultural Services.-Among amphibians, frogs have provided the majority of cultural ecosystem services due to their high visibility and abundance (Hocking and Babbitt 2014). Salamanders, like frogs, are animals that can be seen in zoos and are considered 
easy to care for in the pet trade. Their visibility in both zoos and the farmed pet trade provides value to children and families as a connection to nature and as pets. Salamanders have also appeared in a few children's stories and other novels such as Ray Bradbury's Fahrenheit 451 in which firefighters wore salamander symbols (Hocking and Babbitt 2014). In folklore and legend spread by both Pliny the Elder and Leonardo da Vinci, salamanders have been associated with fire (Hocking and Babbitt 2014; Wake and Koo 2018). The burning of logs gathered from the forest has contributed to the association of salamanders with fire: when gathered wood is burned, resident salamanders may emerge from the burning logs to escape the fire (Wake and Koo 2018).

Provisioning Services. - Salamanders and amphibians are also important for the advancement of medical technology and research. The ability to regenerate limbs and bones has been extensively studied (Song et al. 2010) and researchers are attempting to isolate the regenerative mechanisms to be used in modern medicine (Gupta 2016). However, Sessions and Wake (2020) hypothesize that regeneration may be unique to the salamander genome. Additionally, Taricha newts produce tetrodotoxin skin secretions, which may provide possible treatments in pain management, Parkinson's, Alzheimer's, and other neurological diseases (Lago et al. 2015).

Supporting Services.-Salamanders provide supporting services directly as prey, and indirectly as predators and dispersal agents (Hocking and Babbitt 2014). Salamanders are food sources to other amphibians, reptiles, fish, birds, mammals, and even large invertebrates (Duellman and Treub 1994; Petranka 2010). As predators in aquatic systems, salamanders help regulate tadpole abundance and feeding behavior, indirectly 
affecting algal and aquatic vegetation growth (Morin 1981). In terrestrial ecosystems, salamander predation indirectly reduces decomposition rates by regulating detritivore invertebrate populations on the forest floor (Wyman 1998). After metamorphosis and breeding, through their migration behavior between breeding waters and upland habitat, some salamanders facilitate dispersal and thus facilitate genetic diversity of unrelated species. Mole salamanders (Family: Ambystomatidae) can act as dispersal vectors for other species during migration by transporting small mollusks and the seeds of the burmarigold between pools (Lowcock and Murphy 1990). Additionally, Ambystomid salamanders enhance genetic diversity across environments and between ponds by feeding on viable Colorado Fairy Shrimp (Branchinecta coloradensis) eggs in one pond and defecating in another (Bohonak and Whiteman 1999).

Regulating Services. - The majority of salamander species are predators, and they are often considered the dominant vertebrate predator in mature forests, including oak woodlands, redwood forests, and Douglas-fir forests (Burton and Likens 1975; Petranka et al. 1993; Welsh and Lind 1996; Davic and Welsh 2004). In mature forests, salamander density can be up to seven times greater than in younger forests (Petranka and Murray 2001). In many headwater streams, salamanders are the keystone aquatic predators because fish cannot traverse steep or rocky barriers (Wyman 1998; Brodman et al. 2003; Davic and Welsh 2004).

As keystone predators, salamanders can regulate invertebrate densities in aquatic and terrestrial environments (Davic 1991; Wyman 1998; Davic and Welsh 2004). Some Ambystoma species, for example, reduce mosquito larvae density in wetlands by $98 \%$, 
reducing pests that can vector disease (Brodman et al. 2003; DuRant and Hopkins 2008). Wyman (1998) found that the Red-backed Salamander (Plethodon cinerus) increased detritus and carbon dynamics on the forest floor by feeding on terrestrial detritivores. Ensatinas (Ensatina eschscholtzii) were also found to decrease invertebrate communities and increase carbon capture of forest floors in the Santa Monica Mountains (Best and Welsh 2014). Salamanders also regulate densities and distributions of other amphibian species through competition (Hairston 1996; Walls and Williams 2001).

Bioindicators.-Salamanders can be bioindicators of environmental change and stressors, ranging from anthropogenic toxin and sediment inputs to overall ecosystem health (Welsh and Ollivier 1998; Simon et al. 2000; Townsend and Driscoll 2013). Townsend and Driscoll (2013) found that the Red-backed Salamander (P. cinereus) is a bioindicator for mercury within the forests of the northwestern United States. In addition, ecosystem stress from human-induced sediment inputs can correlate directly with amphibian abundance in redwood forests in California, where increased sediment loads were shown to cause a decrease in amphibian species densities (Welsh and Ollivier 1998). Salamanders can also be utilized to assess the recovery of second-growth forest systems after logging (Ashton et al, 2006). In North American forests, Welsh \& Droege (2001) suggest that plethodontid salamander populations are valuable to monitor ecosystem integrity and biodiversity. Changes in plethodontid salamander populations can be detected more quickly and accurately than other vertebrate species (such as passerine birds, butterflies, small mammals or other amphibians) due to their complex life history, unique physiology, and site fidelity. 
Threats to Salamanders. - Salamanders are often overlooked because they are well hidden and are primarily observed during the rainy season (Petranka 2010). With the variety of ecosystem services that salamanders can provide and their inherent value as an indicator species, it is crucial to understand why they are declining rapidly.

Climate Change.-Anthropogenic climate change is considered a contributing factor for global amphibian species declines (Corn 2005; IUCN 2021). Changes in temperature and precipitation patterns can indirectly affect salamander populations by altering the timing of salamander emergence for breeding which, in turn, affects ecosystem community structure and competitive and predatory interactions (Beebee 1995; Carey and Alexander 2003). Precipitation pattern changes, such as too much or too little rain, can reduce aquatic amphibian populations through egg and larval mortality caused by unseasonable flood flows or earlier drying of pools and ponds (Alford and Richards 1999; Carey and Alexander 2003; Carey et al. 2005). Lack of rainfall may affect terrestrial salamanders through increasingly dry soils and loss of moist cover habitat, which can reduce prey populations and ultimately increase salamander mortality through desiccation (Donnelly and Crump 1998; Alford and Richards 1999).

Pollution.-Agricultural practices contribute to salamander habitat pollution through the use of nitrogen fertilizers (Baker and Waights 1994; Dudgeon et al. 2006). For example, nitrate pollution in aquatic systems reduces the growth rate and survival rate of larval Dwarf Newts (Triturus pygmaeus) (Ortiz-Santaliestra et al. 2007). In male Palmate Newts (Lissotriton helveticus), nitrate exposure reduced growth rates, breathing 
capabilities, and altered the breeding attractiveness of males through the reduction of breeding scent production (Secondi et al. 2013).

Water acidification from air pollution caused female Dwarf Newts (T. pygmaeus) to fail to wrap deposited eggs with leaves of aquatic plants as protection, decreasing the survival of the egg mass (Ortiz-Santaliestra et al. 2007). In Two-lined Salamanders (Eurycea bislineata), mercury contamination disrupted locomotion ability and reduced the success rate of capturing prey (Burke et al. 2010). In urban riparian systems, impervious surfaces and vehicular toxins contribute to urban stream water pollution (Baker and Waights 1994; Davidson et al. 2001), which is correlated with a decrease in both Pacific Tree Frog (Pseudacris regillia) and California Newt (Taricha torosa torosa) populations (Riley et al. 2005).

Urbanization and Roads.-Urbanization and road infrastructure are also linked to pollution and sediment runoff and buildup in riparian systems (Davic and Welsh 2004). Welsh and Ollivier (1998) found that sediment inputs into streams at road construction sites cause amphibian densities to decline. Sediment fills interstitial spaces of stream substrate, which both amphibian species and their prey utilize for cover (Welsh and Ollivier 1998).

The life history patterns of many amphibian species require juvenile, sub-adult, and non-breeding salamanders to locate suitable upland habitat after metamorphosis and breeding (Trenham and Shaffer 2005). Direct road mortality is a significant cause of salamander decline in urban, suburban, and rural environments (Gibbs and Shriver 2005; Marsh et al. 2005; Sutherland et al. 2010). Many salamander species travel long 
distances in terrestrial environments fragmented by roads, in some instances over $8 \mathrm{~km}$ (Twitty et al. 1967), making amphibians vulnerable to road mortality (Carr \& Fahrig, 2001; Baldwin, Calhoun, \& deMaynadier, 2006).

Habitat Loss and Degradation.-Habitat loss can occur with the installation of dams for urban water storage and hydroelectric power (Lind et al. 1996; Brode and Bury 1984). The effects to riparian habitat downstream of dams are well-documented (Lind et al. 1996; Brode and Bury 1984). Fluctuating flow regimes contribute to the decline of amphibian species directly by releasing unseasonably high flows and washing out deposited eggs or indirectly by changing sediment loads and allowing vegetation to narrow channels (Lind et al. 1996). Upstream of dams, riparian habitats are lost when converted into unstable lake habitat with fluctuating water levels (Brode and Bury 1984), causing loss of habitat essential for breeding, rearing, and cover or increases in predatory fish populations (Dudgeon et al. 2006; Brode and Bury 1984).

Agricultural land use changes and timber harvest have similar effects on riparian systems, degrading both aquatic and terrestrial habitat used by many salamanders. Clearing land for agricultural purposes or timber harvest increases sediment loads and air and water temperatures through tree cover loss (Petranka et al. 1993; Jackson et al. 2001). Timber harvest has caused a decline in the Tailed Frog (Ascaphus sp.), Olympic Salamander (Rhyacotriton olympicus), Siskiyou Mountains Salamander (Plethodon stormi), Eastern Newt (Notophthalmus viridescens), and Ambystomid salamanders (Bury 1968; Semlitsch 1998; Brode and Bury 1984). Ashton, Marks, \& Welsh (2006) found 
that timber harvest affected amphibian species richness and densities as much as 60 years after timber harvest.

Introduced Exotic Species and Disease.-The introduction of non-native predatory fish have been reported as the cause of population declines and local extirpations of many salamander species. Specifically, the introduction of Western Mosquitofish (Gambusia affinis) and Red Swamp Crayfish (Procambarus clarki) are linked to the decline of California Newt (T. torosa) in mountain streams in southern California (Gamradt and Kats 1996) and in urban California streams (Riley et al. 2005). An introduced pet tiger salamander species is reducing native populations of the threatened California Tiger Salamander (Ambystoma californiese) through competition and predation, as well as reducing native genetic diversity through hybridization (Riley et al. 2003).

The fungal pathogen known as chytrid fungus (Batrachochytrium dendrobatidis) has been linked to declines and extinction globally of many frog species and populations (AmphibiaWeb. 2011. An Overview of Chytridiomycosis. Available from https://amp hibiaweb.org/chytrid/chytridiomycosis.html [Accessed 5 July 2021]). In 2013, a new form of chytrid fungus that affects salamanders, Batrachochytrium salamandrivorans (Bsal), was described as an endemic species in Asia, and it is presumed to have been introduced to other localities by the amphibian pet trade (Martel et al. 2013; Grant et al. 2016). In a laboratory setting, Bsal was found to be lethal to salamanders in the United States, a global hotspot of salamander biodiversity (Wiens 2007; Grant et al. 2016), and Bsal was reported as the cause of unusual mortality of fire salamanders (Salamandra salamandra) in Europe (Martel et al. 2013). 
Genus Taricha.-The genus Taricha (Family: Salamandridae) is a group of toxic salamanders found in the western United States and Canada that consists of four species: Rough-skinned Newt (Taricha granulosa), California or Coast Range Newt (Taricha torosa), Sierra Newt (Taricha sierrae) and Red-bellied Newt (Taricha rivularis) (Twitty 1942; Twitty 1966; Stebbins 2003). Taricha newts all secrete a specific tetrodotoxin or neurotoxin, the same toxin found in pufferfish (Family: Tetraodontidae), that causes paralysis when ingested or injected (Twitty 1937; Twitty 1966; Hague et al. 2016).

All Taricha ranges overlap, creating areas in which two, and sometimes three, of the species are sympatric (Marks and Doyle 2005; Petranka 2010). During the breeding season for each species, males develop smooth skin, long flattened tails, swollen vents, and hardened toe tips or nuptial pads (Oliver and McCurdy 1974). Hybridization with viable offspring can occur between T. rivularis and any other Taricha species through artificial fertilization in a laboratory setting (Twitty 1966), but it is unlikely to occur naturally due to species-specific mate attractants (Davis and Twitty 1964) and possibly other aspects of niche differentiation. In riparian systems where ranges overlap, $T$. granulosa and $T$. torosa breed in ponds or streams with slow-flowing water and pools. $T$. rivularis, on the other hand, is considered an obligate stream breeder in its known northern range, preferring streams with fast-flowing water (Twitty 1942).

Taricha granulosa.— Rough-skinned Newts (T. granulosa), the largest Taricha newts, range between 12.5 and $22 \mathrm{~cm}$ total length (TL) (Taylor 1984; Neish 1971), with light-brown to dark-brown dorsal coloration and a light-yellow to orange ventral. $T$. granulosa eyes have yellow irises, and their eyelids are uniformly dark (Stebbins 2003). 
T. granulosa occurs on the west coast of the United States, between southeastern Alaska and San Francisco Bay Area, California, with two isolated (and possibly introduced) populations in the Rocky Mountains of Idaho and Montana (Nussbaum and Brodie 1971). Habitat requirements for T. granulosa include lakes, ephemeral ponds, or slow-flowing sections of streams in forested mountains and foothills, and sometimes grasslands (Petranka 2010). Although T. granulosa can inhabit many different freshwater habitats and streams, it is rarely found in fast-flowing water (Petranka 2010). T. granulosa oviposition occurs after mating, and females attach eggs singly to aquatic vegetation, roots, or other detritus. Larvae in stream environments are secretive during the day, hiding under vegetation and rocks, and they are generally found in warm microhabitats and edges of the stream (Licht and Brown 1967).

Timing of migrations to and from breeding locations, as well as breeding, oviposition, and larval metamorphosis, all vary throughout the range for this species, and breeding has occurred in every month except November (Petranka 2010). In the Marion Lake population, both males and females arrive mid-April and leave in mid-September (Neish 1971). The females in Vancouver Island migrate in the spring and remain until September, while males remain in aquatic locations year-round (Oliver and McCurdy 1974). In high elevations, breeding usually occurs in summer and early autumn, but in high-elevation California lakes, gravid females have been observed as late as midOctober (Garber and Garber 1978; Oliver and McCurdy 1974). Conversely, peak oviposition occurs in lower elevations of California in early March through early April and has been documented as early as January (Twitty 1935). Egg incubation generally 
lasts between 20 and 26 days to hatch (Petranka 2010). Timing for larvae to metamorphose ranges from 4 to 5 months in low elevations to almost a year in highelevation cold lakes (Petranka 2010).

Taricha torosa.-California Newts (T. torosa) are also large salamanders, ranging from 12.5 to $20 \mathrm{~cm} \mathrm{TL}$ (Riemer 1958). T. torosa is very similar to T. granulosa in appearance, making the two species difficult to distinguish in the field in areas where they co-occur. Key identifying characteristics include that $T$. torosa has vomerine teeth that form a Y-shape, lighter-colored lower eyelids, and eyes that extend beyond the margin of the head when observed from above (Stebbins 2003; Petranka 2010), as well as the behavioral difference that $T$. granulosa curls the tip of the tail into a coiled form when in an unken reflex or defense posture, while $T$. toros $a$ will hold the tail tip straight (Riemer 1958).

T. torosa's range extends from northwestern California in Mendocino County to Southern California peninsular ranges in San Diego County, and it is found in a variety of habitats in forests, oak woodlands, chapparal, and grasslands from sea level to 2,000 m elevation. Adults breed in both pond and lake habitats and slow-flowing stream habitats (Petranka 2010).

Breeding usually lasts between 6 to 12 weeks, but the breeding season varies for $T$. torosa from December to early May, depending on location, and amplexing pairs have been observed as early as late September (Petranka 2010). In some locales, breeding can have two peaks, with pond-breeding occurring between December and January, while stream-breeding populations breed around March, when storms have subsided for the 
season (Twitty 1942; Petranka 2010). The breeding period has even been found to differ between a breeding stream and a pond that are $0.5 \mathrm{~km}$ apart (Marchetti and Hayes 2020).

After breeding, females oviposit spherical egg masses on vegetation, roots, and rock in ponds or streams, and even directly onto the bottom of ponds (Twitty 1942; Stebbins 2003; Petranka 2010). Egg mass incubation varies with water temperature, with estimates ranging from 52 days in west-central California to 14 to 21 days in southern California (Mosher et al. 1964). Larvae usually transform during late-summer to earlyautumn (Riemer 1958) and disperse after metamorphosis.

The southern populations of $T$. torosa, from Monterey County to San Diego County, are listed as a Priority 2 Species of Special Concern (Thomson et al. 2016). This designation is due to extirpations and declining populations in areas with large or dense human populations in which development, water diversions, and introduced predators have caused habitat loss and degradation of both breeding habitat and terrestrial habitat (Thomson et al. 2016). In streams in southern California, evidence suggests that introduced crayfish and mosquitofish feed heavily on T. torosa egg masses, drastically affecting local populations (Gamradt and Kats 1996). At present, northern populations of T. torosa warrant no special conservation status on a regional or national level (Thomson et al. 2016).

Taricha rivularis. - Red-bellied Newts (T. rivularis) can be described as a medium to large stocky salamander with dark brown dorsal coloration and bright red ventral coloration. As with all Taricha species, T. rivularis has rough granular skin, which becomes smooth during the breeding season. The eyes of $T$. rivularis are a solid dark 
brown color, compared to the yellow and silver coloration of other Taricha species (Stebbins 2003). Research using individual markings has estimated that $T$. rivularis lives between 20 and 30 years (Twitty 1966; Hedgecock 1978).

The geographic range of $T$. rivularis includes Humboldt County, Lake County, Sonoma County Mendocino County, and newly as of 2009, Santa Clara County, California (Marks and Doyle 2005; Reilly et al. 2014). The new population of $T$. rivularis was discovered in the Santa Cruz Mountain Range approximately $130 \mathrm{~km}$ south of and across the San Francisco Bay from, the closest northern population. Although the southern population is not genetically dissimilar to the population in northern portion of its range, it is unclear if the population is introduced because low genetic diversity of the species prevents meaningful genetic comparisons (Kuchta and Tan 2006; Reilly et al. 2014). Based on genetic evidence from T. rivularis populations in the north, low variation may have been caused by rapid population expansion following a genetic bottleneck (Kuchta and Tan 2006; Reilly et al. 2014).

Habitat requirements of $T$. rivularis are poorly understood due to few investigations of the species. Although T. rivularis is generally found in the California coastal redwood belt, it is not restricted to coast redwood forests (Packer 1960; Stebbins 2003; Reilly et al. 2014). The southern population is found in a mixed evergreen forest within the Stevens Creek watershed with redwood forests nearby (Reilly et al. 2014). Aquatic habitat of $T$. rivularis for the northern population has been described as mountain brooks with clean, fast-flowing water (Twitty 1966; Stebbins 2003), however, no additional microhabitat requirements have been described. The terrestrial habitat has also not been described, 
other than broad forest types and the presence of California bay laurel (pepperwood) (Twitty 1966; Stebbins 2003).

Homing migration and breeding ecology of $T$. rivularis, in contrast, were extensively studied in one "experimental stretch" of Pepperwood Creek in Sonoma County (Packer 1960; Davis and Twitty 1964; Twitty et al. 1964; Twitty 1966; Grant et al. 1968). In this location, Twitty and others (1964) observed the homing migration of breeding adult $T$. rivularis individuals returning to the original 15 meter $(\mathrm{m})$ segment of stream after artificial displacement over $8 \mathrm{~km}$ away. Through artificial and surgical manipulation of the visual and olfactory senses, the authors further determined that $T$. rivularis uses smell as a homing mechanism to return to its natal stream segment (Twitty et al. 1964; Twitty 1966; Grant et al. 1968). Grant and others (1968) concluded that an individual $T$. rivularis imprints on the scent of its natal stream habitat just after metamorphosis.

Breeding migrations of northern T. rivularis populations start in late January and continue until May (Davis and Twitty 1964; Twitty et al. 1964; Twitty et al. 1964). Males arrive at the stream first, and, upon the arrival of the first females, breeding congregations form, and mating begins (Davis and Twitty 1964). After mating, females travel to areas of fast-flowing, well-oxygenated water and deposit egg clusters to the bottoms or edges of large rocks (Davis and Twitty 1964). In some locations where adult T. rivularis densities are high, up to 70 egg masses have been found on the bottom of a small stone (Twitty 1935; Twitty 1942). When the breeding season is complete, individuals leave the stream and find refuge underground until the first heavy winter rains 
stimulate individuals to emerge to forage for insects and other invertebrates (Twitty 1966).

In a laboratory setting, egg incubation lasts 16 to 20 days at 23 degrees Celsius and 30 to 34 days at 15 degrees Celsius, and the larval stage of $T$. rivularis lasts 4 to 6 months (Licht and Brown 1967). Although larvae are found in pools, specific adaptations such as a streamlined body shape with more developed limbs and reduced balancers allow the larvae to survive the mountain brook habitat (Davis and Twitty 1964; Twitty 1966; Licht and Brown 1967). After metamorphosis, juveniles migrate upland to find underground shelter, where they remain until they reach maturity at approximately five years (Twitty 1955; Twitty 1966).

T. rivularis is a California endemic species that is an obligate stream-breeding and rearing salamander that utilizes habitats susceptible to anthropogenic habitat loss and degradation. Much of the habitat in the T. rivularis range is threatened by timber harvest, agricultural practices, and urbanization (Reilly et al. 2014; Thomson et al. 2016). Because $T$. rivularis is such a poorly-studied species, more research is needed to protect critical habitat components and provide for species recovery (Thomson et al. 2016).

No habitat research has not been conducted on the Santa Clara County T. rivularis population (Reilly et al. 2014) let alone on the species throughout its range. T. rivularis is a long lived specialized salamanders with strong site fidelity (Twitty et al. 1964; Hedgecock 1978), the Santa Clara Population of T. rivularis has the potential to be a bioindicator of environmental and ecological stress from anthropogenic influences (Welsh and Ollivier 1998). The habitat of the disjunct Santa Clara County population 
may serve as a habitat refugium in the face of unknown future climate scenarios (Lesica and Allendorf 1995; Reilly et al. 2014).

This study assesses the breeding range, timing and the aquatic mesohabitat preferences of this important Santa Clara County population of $T$. rivularis in the context of its sympatric congeners. Information provided is intended to aid resource managers in protecting this disjunct population and a California Species of Special Concern along with T. granulosa and T. torosa in this unique ecosystem.

\section{OBJECTIVES AND RESEARCH QUESTIONS}

The objective of this research was to gather distribution and habitat data on the disjunct Santa Clara County population of Red-bellied Newts (T. rivularis). Specifically, I answer the questions: Where is the southern population found? In the context of sympatry with rough-skinned newts (T. granulosa) and California Newts (T. torosa) what are the phenology and mesohabitat preferences of males during the breeding season and oviposition site selection of females?

\section{Research Questions.-}

RQ1: Southern population range: What is the current range of the southern population of T. rivularis?

RQ2: Southern population breeding phenology

a: What is the timing of breeding migrations of the southern population T. rivularis, as compared with sympatric newts and other salamanders encountered?

b: How does spatial aggregation of males of the southern population of $T$. rivularis vary throughout its breeding season in each occupied stream? 
RQ3: Male habitat use and availability

c: How does mesohabitat availability compare between $T$. rivularis breeding versus non-breeding streams?

d: How does Taricha newt mesohabitat use compare with available mesohabitats in T. rivularis-occupied reaches?

e: How do aquatic mesohabitat, substrate and cover preferences of adult male $T$. rivularis differ from these preferences for sympatric congeners?

RQ4: How does female T. rivularis habitat selection for oviposition site differ from interspersed random sites within Stevens Creek? 


\section{ChAPTER 2}

\section{INTRODUCTION}

Amphibians are among the most threatened group of vertebrates in the world, and global population declines are well documented (Wake 1991; Alford and Richards 1999; IUCN 2021). Threats are largely anthropogenic, including global climate change, pollution, urbanization, habitat loss, habitat degradation, and introduced exotic species and disease (Dudgeon et al. 2006). Many amphibian population declines are not attributed to a single factor but rather a combination of variables that are not always identified; many field studies only focus on single factors (Davidson and Knapp 2007). Lack of understanding of the multifactorial causes of population declines and limited knowledge of life history patterns can impair conservationists' ability to protect a species (Bishop et al. 2012).

The Red-bellied Newt (Taricha rivularis), a highly specialized salamander species, is particularly vulnerable. Despite its status as a California Priority 2 Species of Special Concern, data on T. rivularis are lacking. Most knowledge of the species comes from one extensively studied population in an "experimental stretch" of Pepperwood Creek in Sonoma County, California, USA (Packer 1960; Davis and Twitty 1964; Twitty et al. 1964; Twitty 1966; Grant et al. 1968). In 2009, a new population of $T$. rivularis was discovered in the Santa Cruz Mountain Range in Santa Clara County, California, USA. Data from this population will provide insights on how to protect the species throughout its range. 
T. rivularis is a medium to large stocky salamander that occurs from Humboldt County, California, USA to Sonoma County, California, USA and, as of 2009, in Santa Clara County, California, USA (Marks and Doyle 2005; Reilly et al. 2014). Habitat requirements of $T$. rivularis are poorly understood. Victor Twitty (1966) simply described the terrestrial habitat of $T$. rivularis as broad forest types with the presence of "Pepperwood" or California Bay Laurel (Umbellularia californica). However, the species is generally found in, but not restricted to, the California Coast Redwood (Sequoia sempervirens) belt (Packer 1960; Stebbins 2003; Reilly et al. 2014). Aquatic habitat of $T$. rivularis for the northern population has been described as mountain brooks with clean, fast-moving water (Twitty 1966; Stebbins 2003); however, no additional microhabitat requirements have been described.

Breeding ecology and migrations of $T$. rivularis, in contrast, were extensively studied in an experimental stretch of Pepperwood Creek (Packer 1960; Davis and Twitty 1964; Twitty et al. 1964; Twitty 1966; Grant et al. 1968). Twitty and others (1964) documented and experimented with the mechanisms of homing migration of $T$. rivularis individuals returning to the original $15 \mathrm{~m}$ segment of stream after artificial displacement over $8 \mathrm{~km}$ away. Breeding migrations of northern T. rivularis populations begin in late January, arriving in the stream around late February to early March after heavy storms subside, and continue until May (Davis and Twitty 1964; Twitty et al. 1964; Twitty et al. 1964). Males arrive at the stream first and, upon the arrival of the first females, breeding congregations form, and mating begins (Davis and Twitty 1964). After mating, females travel to areas of fast-flowing, well-oxygenated water and deposit egg clusters to the 
bottoms or edges of large rocks (Davis and Twitty 1964). In some locations where adult T. rivularis densities are high, up to 70 egg masses have been found on the bottom of a single stone (Twitty 1935; Twitty 1942). When the breeding season is complete, individuals leave the stream and find refuge underground until the first heavy winter rains stimulate individuals to emerge to forage for insects and other invertebrates (Twitty 1966).

Taricha rivularis is an obligate stream-breeding and -rearing salamander that utilizes habitats susceptible to anthropogenic habitat loss and degradation (Twitty 1966; Marks and Doyle 2005; Petranka 2010). Habitat loss due to land use changes, logging practices, and human road expansion degrades stream habitat with pollution and sediment inputs and fragments migratory habitat (Corn and Bury 1989; Jackson et al. 2001; Peterman et al. 2008). Much of the habitat in the T. rivularis range is threatened by timber harvest, agricultural practices, and urbanization (Reilly et al. 2014; Thomson et al. 2016). Because $T$. rivularis is such a poorly-studied species, more research is needed to protect critical habitat components and provide for species conservation (Thomson et al. 2016).

No habitat research has previously been conducted on the Santa Clara County $T$. rivularis population in the upper Stevens Creek headwater tributaries (Reilly et al. 2014). As specialized riparian forest salamanders with long life spans and strong site fidelity (Twitty et al. 1964; Hedgecock 1978), this population of T. rivularis has the potential to be a bioindicator of environmental and ecological stress from anthropogenic influences (Welsh and Ollivier 1998). In addition, the habitat of the disjunct Santa Clara County 
population of $T$. rivularis, may serve as a habitat refugium in the face of unknown future climate scenarios (Lesica and Allendorf 1995; Reilly et al. 2014).

In addition, Santa Clara County harbors three of the Taricha species: T. rivularis, $T$. granulosa and T. torosa. All Taricha ranges overlap, creating areas in which two, and sometimes three, of the species are sympatric (Figure 1) (Marks and Doyle 2005; Petranka 2010). In riparian systems where ranges overlap, T. granulosa and T. torosa breed in ponds or streams with slow-moving water and pools. T. rivularis, on the other hand, is considered an obligate stream breeder in its known northern range, preferring streams with fast-flowing water (Twitty 1942). Minimal investigatory research has looked into how these three species interact within an ecosystem are lacking.

The largest of the Taricha salamanders is the Rough-skinned Newt (T. granulosa) (Taylor 1984; Neish 1971) that ranges geographically from southeastern Alaska to the San Francisco Bay Area, California, with two isolated (and possibly introduced) populations in the Rocky Mountains of Idaho and Montana (Nussbaum and Brodie 1971). Habitat requirements for T. granulosa include lakes, ephemeral ponds or slow-flowing sections of streams in forested mountains and foothills, and sometimes grasslands; rarely is T. granulosa found in fast-flowing waters (Petranka 2010). Timing of migration, breeding, oviposition and larval metamorphosis vary throughout the range for this species. Peak oviposition occurs in lower elevations of California in early March through early April, and oviposition has been documented as early as January (Twitty 1935). 


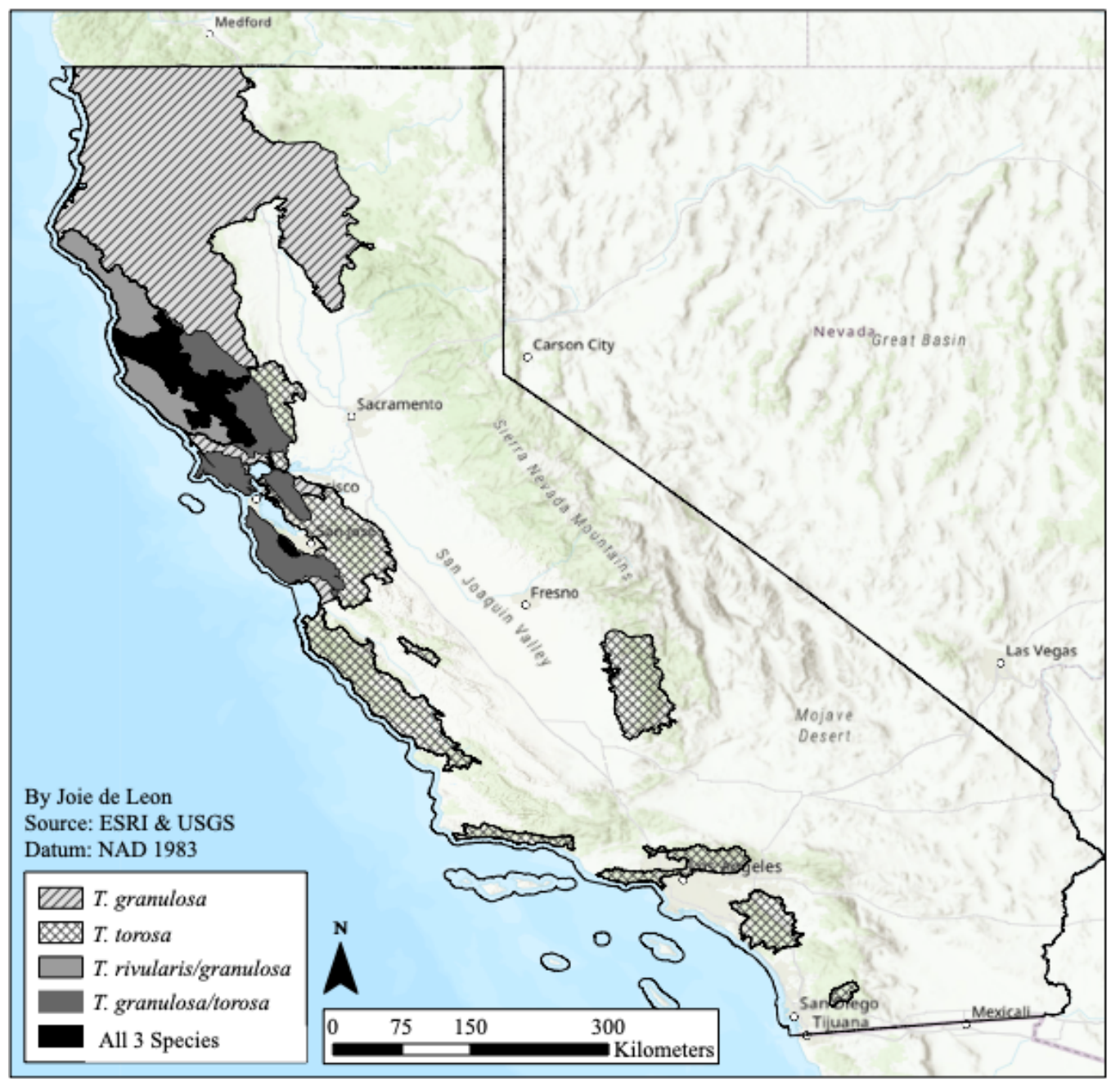

Figure 1. California ranges of T. rivularis, T. granulosa (diagonal lines), and T. torosa (hatched lines) locations where ranges overlap. The entirety of $T$. rivularis range is shared with $T$. granulosa (light gray).

California Newts (T. torosa) are also large salamanders, very similar to $T$. granulosa in appearance, making the two species difficult to distinguish in the field in areas where they co-occur. T. torosa ranges from northwestern California in Mendocino County to Southern California peninsular ranges in San Diego County. The southern populations of T. torosa, from Monterey County to San Diego County, are listed as a Priority 2 Species of Special Concern (Marchetti \& Hayes, 2020). This designation is due to extirpations 
and declining populations in areas with large or dense human populations in which development, water diversions, and introduced predators have caused habitat loss and degradation of both breeding habitat and terrestrial habitat (Thomson et al. 2016).

Habitat requirements include lakes, ponds or slow-flowing sections of streams in forests, oak woodlands, chapparal, and grassland (Petranka 2010). Southern populations have been found depositing eggs in faster-flowing streams (Gamradt and Kats 1997). The breeding season varies from December to early May, depending on location (Petranka 2010). In some locales, breeding can have two peaks, with pond-breeding occurring between December and January, while stream-breeding populations breed around March, when storms have subsided for the season (Twitty 1942; Petranka 2010). The breeding period has even been found to vary between a breeding stream and a pond $0.5 \mathrm{~km}$ apart (Marchetti and Hayes 2020).

This study assesses and attempts to fill some knowledge gaps on T. rivularis and the interactions with sympatric newts, $T$. granulosa and $T$. torosa. The distribution, breeding range, timing of breeding migrations and the aquatic mesohabitat preferences of this Santa Clara County population of $T$. rivularis in the context of its sympatric congeners. Information provided is intended to aid resource managers in protecting this disjunct population of a California Species of Special Concern, along with T. granulosa and $T$. torosa, in this unique ecosystem.

\section{MATERIALS AND MeTHOdS}

Study Area.-I conducted this study in Upper Stevens Creek County Park and Midpeninsula Regional Open Space District (MROSD) park properties, including Monte 
Bello Open Space Preserve, Skyline Ridge Open Space Preserve, and Long Ridge Open

Space Preserve. These locations are within the Santa Cruz Mountain Range in Santa

Clara and San Mateo Counties, California, USA, approximately $58 \mathrm{~km}$ south of San

Francisco and $20 \mathrm{~km}$ west of San Jose (Figure 2).

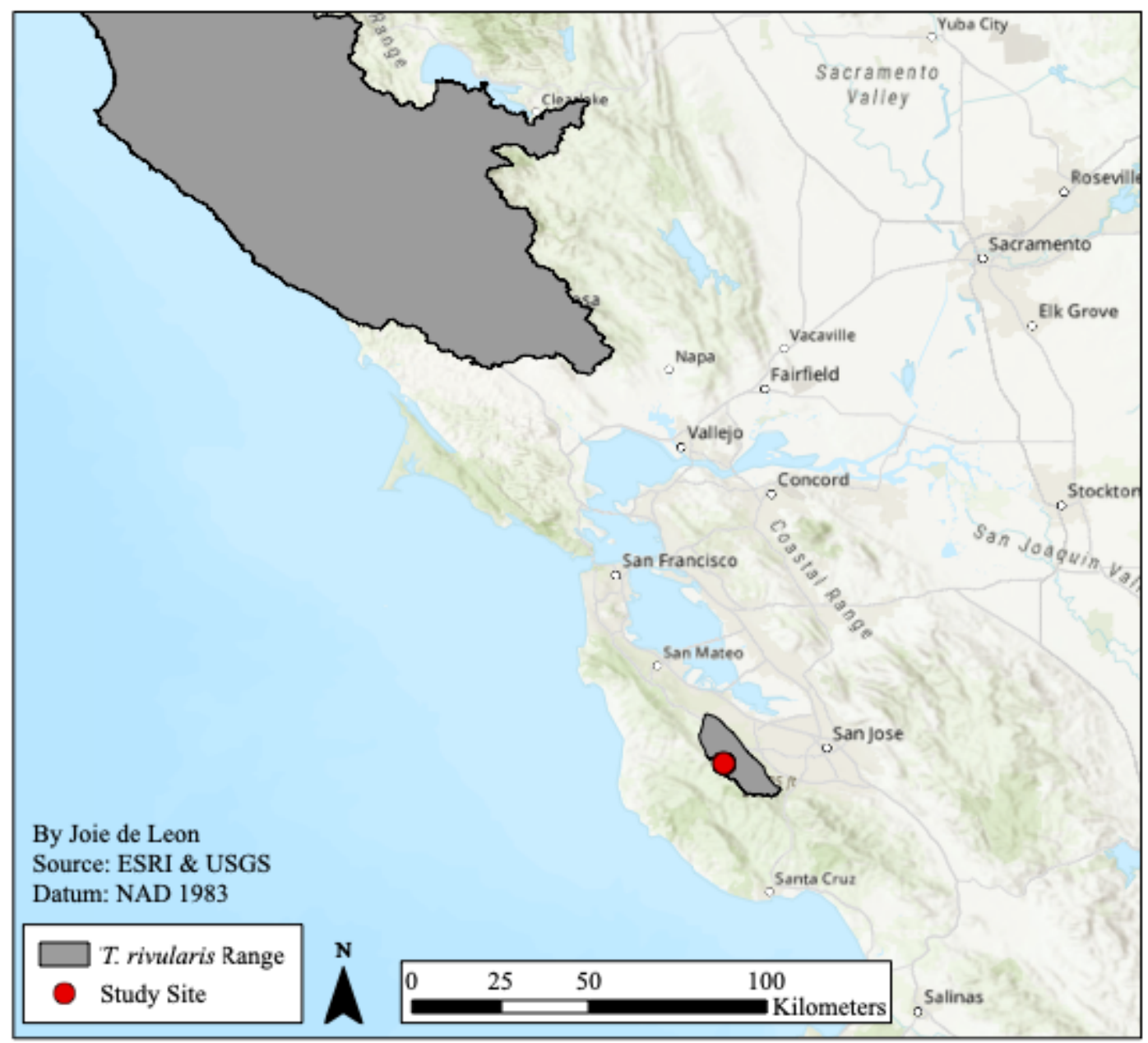

Figure 2. Map of T. rivularis range around the San Francisco Bay Area in gray. The red dot represents our study site in the Stevens Creek watershed in Santa Clara County.

In 2018, I surveyed the publicly accessible tributaries of Upper Stevens Creek, including a tributary colloquially named by MROSD Staff as "Twitty" Creek; the 
adjacent headwaters of the upper San Gregorio Creek watershed of Lambert Creek and its tributaries; and a small portion of Peter's Creek in the headwaters of the upper Pescadero Creek watershed. Stream sampling was limited to MROSD property and Santa Clara County Parks Upper Stevens Creek Park, as sampling on private property was not possible.

I reduced the study area in 2019 to only include the two stream reaches within the Stevens Creek Watershed in which T. rivularis was found in the 2018 surveys: Stevens Creek Reach 4 and Twitty Creek.

Dense mixed evergreen Douglas-fir forest with interspersed redwoods surrounds much of Upper Stevens Creek watershed above the reservoir. Oak-woodland forest and nearby grasslands that have been historically used for cattle grazing are also present (MROSD. 2016. Monte Bello Preserve. Available from https://www.openspace.org/ preserves/monte-bello [Accessed 5 July 2021]). The Stevens Creek watershed drains approximately $75 \mathrm{~km}^{2}$ into the San Francisco Bay Estuary, just north of Moffett Field Naval Air Station. Stevens Creek begins at Black Mountain in the Monte Bello Open Space Preserve and passes through Upper Stevens Creek County Park, Santa Clara County. One major impoundment, Stevens Creek Reservoir, provides winter runoff storage for the Santa Clara Valley Water District and maintains a wet channel to preserve federally endangered steelhead (Leidy et al. 2005).

Both Upper Stevens Creek and Twitty Creek are well-entrenched channels, with some areas of sinuosity and less entrenched channels. Boulder and cobble are the dominant substrates, but gravel and sand are also interspersed throughout the study area. The 
majority of the channels surveyed are densely canopied with Douglas-fir (Pseudotsuga menziesii), California Buckeye (Aesculus californica), Pacific Madrone (Arbutus menziesii), White Alder (Alnus rhombifolia), and willows (Salix spp.), with Coast Redwood (Sequoia sempervirens), Coast-live Oak (Quercus agrifolia), Big-leaf Maple (Acer macrophyllum), and Tan-oak (Notholithocarpus densiflorus) also present. Sword Fern (Polystichum minunitum), Poison Oak (Toxicodendron diversilobum), California Stinging Nettle (Urtica dioica), Trailing Blackberry (Rubus ursinus), Thimbleberry (Rubus parviflorus), Western Coltsfoot (Petasites palmatus), and many other herbaceous groundcover species are present along banks and flood plains of the less-entrenched areas of stream.

Many other wildlife species also use the watershed. The mesocarnivores, such as the Gray Fox (Urocyon cinereoargenteus), Bobcat (Lynx rufus) and raptors, are not threats to Taricha due to its tetrodotoxin (Twitty 1937; Twitty 1966; Hanifin 2010; Vaelli et al. 2020). Other mammals, including the American Badger (Taxidea taxus), the Duskyfooted Woodrat (Neotoma fuscipes) and other burrowing mammals, potentially create terrestrial refugia in the form of burrows for amphibious species (Vestal 1938; Trenham 2001; Trenham and Shaffer 2005; Innes et al. 2007). Multiple snake species, including the Common Garter Snake (Thamnophis atratus) and its sub-species, the Santa Cruz Garter Snake (T. a. atratus), are present near Stevens Creek (Stebbins 2003). The Common Garter Snake and the Santa Cruz Garter Snake are among the few known predators capable of surviving the Taricha tetrodotoxin (Brodie 1968; Williams et al. 2010). A few fish species, including Rainbow Trout (Oncorhynchus mykiss) (historically 
Steelhead Trout, prior to building Stevens Creek Reservoir) use the Stevens Creek watershed (Leidy et al. 2005; Jerry Smith unpubl. report). In addition to the Taricha newts, other salamanders in the watershed include the Pacific Giant Salamander (Dicamptodon ensatus) and the terrestrial California Slender Salamander (Batrachoseps attenuatus), Ensatina (Ensatin eschscholtzii), Arboreal Salamander (Aneides lugubris) and Santa Cruz Black Salamander (A. flavpunctatus) (Stebbins 2003).

Study Design. - I conducted visual encounter surveys in 2018 to identify stream reaches within all the watersheds sampled that supported detectable populations of $T$. rivularis. Visual encounter surveys record the presence of T. rivularis, but they do not determine absence. From March to April 2018, I conducted 12 timed visual encounter surveys in tributaries and streams adjacent to Twitty Creek in the Stevens Creek watershed and Pescadero and San Gregorio watersheds.

In 2019, I conducted visual encounter surveys for all newts and salamanders from March to May 2019, for a total of nine surveys, four in Twitty Creek and five in Stevens Creek. Surveys began later in the season than in 2018 due to heavy storms causing high flows and turbidity in February and early March (Figure 3).

For each T. rivularis individual encountered on each survey date, I recorded the GPS coordinate to evaluate intraspecific distributions. I used aggregated distributions as an indicator of active breeding activity habitat within the occupied range (Packer 1963; Twitty 1966). In addition to GPS location, I recorded the sex and age class of each individual. 


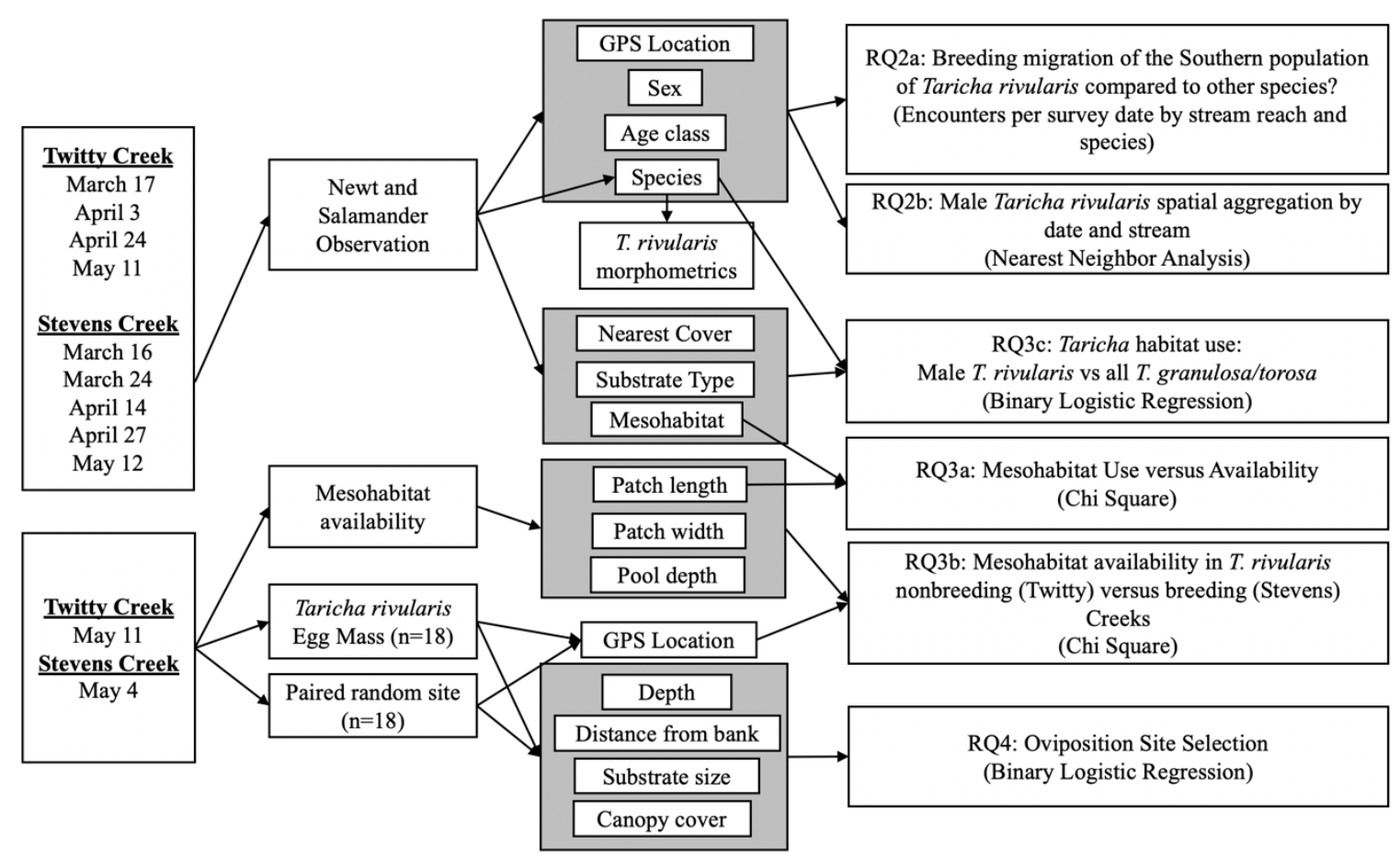

Figure 3. Study design for 2019 surveys.

I mapped the overall mesohabitat data for Stevens and Twitty Creeks to compare the relative availability of different mesohabitats across the two stream reaches. I characterized aquatic mesohabitat type, substrate type, and nearest cover type preferences for breeding adults of all Taricha species as I encountered them in the field. I then compared the overall percentages of mesohabitats used by each species with available mesohabitats to assess the selectiveness of each species. I recorded mesohabitat, substrate and cover preferences of each Taricha individual observed during 2019 surveys by date and location to assess differences in habitat preference between $T$. rivularis and sympatric congeners.

Once breeding was completed and all adult $T$. rivularis had left the stream, I conducted egg mass surveys. For each oviposition site located, I randomly selected a 
paired unoccupied site within ten possible oviposition sites. I collected data on habitat characteristics for all sites where I detected egg masses and for paired randomly chosen sites to characterize breeding female habitat selectivity.

Data Collection.-For the initial 2018 surveys, two to four observers started from a predetermined accessible location and walked either upstream or downstream until the end of the planned stretch or until the stream was no longer accessible due to property ownership, personal safety in accessing the area, or physical ability to walk along the channel. Observers actively searched for $T$. rivularis or any other newt or salamander species within the stream, along the banks, and in any location within a meter of the bank.

I did not handle pairs and groups found in amplexus, and therefore did not sex or measure, to avoid disrupting reproductive behaviors. For all other T. rivularis encountered, I captured (with wet hands), identified, measured the total length (TL) and snout-vent length (SVL), using a metric ruler to the nearest millimeter ( $\mathrm{mm}$ ), weighed to the nearest gram with a Pesola spring scale, and recorded the age class (adult or juvenile) and sex of each individual. Breeding males have a swollen vent with a black bar across the vent, presence of smooth skin, and a long flattened tail (Twitty 1942; Twitty 1966). After collecting data, I immediately released the individual in the same location in which it was captured and recorded the GPS coordinates. For T. granulosa or T. torosa, observers captured, identified, and then immediately released them at the location of capture. I did not capture GPS coordinates for T. granulosa or T. torosa. In many instances, specific morphological separation of $T$. granulosa versus $T$. torosa was not 
possible due to their similar biometrics, so I recorded those individuals as indeterminate T. granulosa/torosa. I also recorded GPS coordinates of Dicamptodon ensatus encountered but did not handle individuals.

In 2019, I conducted surveys again with two to four observers walking upstream along the channel while actively searching for any newt or salamander species. As in 2018, observers captured with wet hands and identified, measured for TL and SVL, and sexed $T$. rivularis adults (not in amplexus) and juveniles. In Stevens Creek, due to the large numbers of $T$. rivularis individuals I encountered, I only measured and recorded every tenth $T$. rivularis observation measured and recorded. I captured the entire group present at each tenth observation and individuals I sexed and measured as described above. I recorded GPS coordinates for each $T$. rivularis and D. ensatus observed. I captured T. granulosa and T. torosa for identification purposes only.

I recorded mesohabitat type, substrate type, and nearest cover type for each salamander observed (see Figure 3). I defined instream mesohabitats as pool, run, riffle, or cascade (Hawkins et al. 1993), and bank is also used for individuals that I observed outside of the wetted channel. Pool is defined as deep areas of slow-flowing water with low gradient and fine sediment. A run is defined as non-turbulent fast-flowing water with a low gradient. A riffle is defined as turbulent fast-flowing water with a steeper gradient and coarser sediment. Cascade is defined as turbulent fast-flowing water with a steep gradient and larger boulders (Hawkins et al. 1993). Substrate type is identified as: silt or organic matter; sand; gravel or pebble $(2-64 \mathrm{~mm})$; cobble $(64-256 \mathrm{~mm})$; boulder $(>256$ mm); or bedrock (Bury and Corn 1991). Nearest cover type is defined as large woody 
debris, overhanging vegetation, water depth, rocks, boulders, and loose streambed material.

I conducted surveys to assess overall mesohabitat availability on 4 May 2019 in Stevens Creek and on 11 May 2019 in Twitty Creek, starting at the Twitty-Stevens confluence, as for the visual encounter surveys. I measured with a transect tape and recorded by mesohabitat type the length and width of each mesohabitat patch in each stream reach. I determined the maximum depth of each pool using a metric ruler.

I conducted egg mass surveys on these two dates as well, 4 May 2019 in Stevens Creek and on 11 May 2019 in Twitty Creek. While walking upstream, I surveyed by reaching into interstitial spaces of cobbles and boulders while feeling gently for egg masses. I never moved substrate during the search process to prevent any disturbance or dislodgement of egg masses. Because newts can fit in much smaller spaces than the hands of surveyors, it is assumed that the search for egg masses was not exhaustive. Adjacent to each site with at least one egg mass, I selected a paired unoccupied site using a random number generator to move between one and ten potential oviposition sites either upstream or downstream of the egg mass location.

At each egg mass site and each paired unoccupied site, I collected the following data: number of egg masses; egg mass depth; position in stream (left, center, or right when looking downstream); distance from both left and right bank; attached substrate type (cobble, boulder, woody debris); attached substrate size $\left(\mathrm{cm}^{2}\right)$; mesohabitat type (pool, run, riffle); and canopy cover (Forestry Suppliers Spherical Crown Densiometer). 
Data Analysis.-I used ArcGIS Pro 2.7 (ESRI, Redlands, California USA) to document the presence of Taricha rivularis in its southern range. I assessed whether the distribution of observed T. rivularis was clustered, dispersed, or randomly distributed on each date in each location sampled using the average nearest neighbor (ANN) tool in ArcGIS Pro 2.7. The ANN tool tests whether the average distance between a set of points is greater or less than a hypothetical random distribution (the null hypothesis) or indistinguishable from it (the alternate hypothesis). If $P>0.05$, the null hypothesis is accepted, and the points are considered randomly distributed. If $P<0.05$ and the $z$-score is $<-1.96$ or $>+1.96$, the null hypothesis is rejected, and the nearest neighbor ratio (NNR) is used to assess aggregation. The NNR is the observed mean distance / expected mean distance in a given area. If NNR $>1.0$, the distribution is over-dispersed; if NNR $<$ 1.0, the distribution is clustered or aggregated (Andy Mitchell 2005). I ran ANN analysis across all survey dates combined for each creek and each survey date and each creek separately.

I recorded by date all encounters of $T$. rivularis individuals and other newts and salamanders to describe seasonal movements of Taricha rivularis and sympatric salamander species. Due to the high variability in time needed to process and record data depending on the numbers of $T$. rivularis encountered, I utilized total catch per survey date as the unit of measure rather than catch-per-unit-effort.

I summarized available mesohabitat percentages for each surveyed reach and ran a chi-square goodness-of-fit test in R (R Development Core Team 2017) to assess differences among percentages of each mesohabitat type in each occupied stream. 
I summarized percent habitat use data for each newt or salamander species and compared the mesohabitat-use percentages for the three Taricha species versus the available habitat percentages for each stream reach using a chi-squared goodness-of-fit test. I excluded $D$. ensatus from the comparison due to low numbers.

In preparation for inferential analysis, I grouped or removed species and habitat to strengthen statistical power. I excluded observations in which the mesohabitat was described as "bank" or "cascade" due to low numbers. I removed T. torosa from the analysis due to the low numbers of observations in Stevens Creek and the uncertain specific identification for some T. granulosa/torosa individuals. I combined lowfrequency habitat variables as follows: cover types of "boulder," "cobble," and "bedrock cracks" combined into "interstitial spaces." Cover types "large woody debris," "small woody debris," "woody debris," "organic matter" and "roots" combined into a single cover type: "Organic Matter/Vegetation.” Substrate types "silt/organic matter," "vegetation," "woody debris" and "roots" combined into the substrate type: "Silt/Organic Matter.” Finally, I used only variables within Stevens Creek due to breeding occurring only within Stevens Creek.

I contrasted $T$. rivularis adult male breeding habitat parameters with those of sympatric congeners using a binary logistic regression run through the GLM function in $\mathrm{R}$ (R Development Core Team 2017) with species (T. rivularis versus T. granulosa) as the binary dependent variable. Predictor variables included are mesohabitat (pool, riffle, and run), substrate (boulder/bedrock, cobble, gravel, sand, and silt/organic matter), and 
nearest cover type (interstitial spaces, undercut bank, water depth, woody debris, organic matter/vegetation).

The initial full model that included all habitat variables was reduced by using the dredge, or automated model selection, function in the MuMIn package (Kamil 2020). MuMIn function runs every possible combination of variables and identifies the best fitting model using the AICc and deltaAIC (Burnham and Anderson 2002; Kamil 2020).

To predict the odds that the Taricha newt is either T. rivularis or T. granulosa, I used the binary logistic regression based on the individual's presence in or near a specific habitat variable. In the analysis, one can infer from the coefficient estimate $\beta$, how much proximity to a specific habitat variable increases or decreases the odds of a newt being a T. rivularis on a log scale; standard error (SE); $z$ is the Wald's test value, or how many standard deviations the $\beta$ values are away from 0 on a standard normal curve; Odds Ratio is the exponentiation of $\beta$. Both $\beta$ and the odds ratios are used to interpret the strength of associations among the habitat variables and the Taricha species in Stevens and Twitty Creeks.

For the mesohabitat category, the binary logistic regression analysis used "pool" as the reference variable, the habitat variable against which all the other habitat variables in the category are compared. For substrate, the reference variable was "boulder." For cover type, the reference variable was "interstitial spaces."

I also used a binary logistic regression model to identify associations among habitat variables and the presence/absence of a $T$. rivularis oviposition site. The predictor variables are mesohabitat (pool, riffle, and run), attached substrate (boulder, cobble, and 
wood), substrate size $\left(\mathrm{cm}^{3}\right)$, depth (m), distance from bank (m), and canopy cover. I determined the best possible model as described for adults above. The initial binary logistic regression using the GLM function with all the measured and categorical variables, followed by a dredge analysis with automated model selection, determined that substrate size alone was the best predictor of the presence/absence of a T. rivularis oviposition site. I ran the final binary logistic regression model using only substrate size as the predictor. To confirm the significance of the model, I ran a Mann-Whitney U.

\section{RESULTS}

Range.-In 2018, I recorded a total of 110 T. rivularis individuals and one pair in amplexus between 7 March 2018 and 29 April 2018 in Stevens Creek Reach 4, Twitty Creek, and an unnamed tributary south of the Twitty-Stevens confluence (Table 1). Of the 110 observed individuals, I captured 57 adult males $(\mathrm{SVL}=68.7 \mathrm{~mm} \pm 0.8 \mathrm{~mm}$; range, $51-89 \mathrm{~mm})$ and eight juveniles $(\mathrm{SVL}=27.0 \mathrm{~mm} \pm 1.0 \mathrm{~mm}$; range, $23-32 \mathrm{~mm}) . \mathrm{I}$ found no T. rivularis individuals during surveys in Lambert Creek, in the adjacent watersheds, or in the remaining Stevens Creek reaches or tributaries of Indian Creek, Bay Creek, Gold Mine Creek, and four unnamed tributaries (Table 1). 
Table 1. T. rivularis Observations in Each of the Survey Locations for 2018.

\begin{tabular}{llcc} 
Date & Location & Adult & Juvenile \\
\hline 7-Mar & Twitty Creek & 15 & 7 \\
12-Mar & Lambert Tributary & 0 & 0 \\
18-Mar & Lambert Creek (Lower) & 0 & 0 \\
19-Mar & Lambert Creek (Upper) & 0 & 0 \\
29-Mar & Twitty Creek & 9 & 3 \\
31-Mar & Indian Creek \& Stevens Reach 7 & 0 & 0 \\
4-Apr & Unnamed Tributary \& Twitty Confluence & 3 & 1 \\
11-Apr & Unnamed Tributary (2) \& Stevens Reach 1 & 0 & 0 \\
16-Apr & Unnamed Tributary \& Stevens Reach 2 & 1 & 0 \\
18-Apr & Stevens Reach 4 & 68 & 0 \\
21-Apr & Bay Creek \& Stevens Reach 6 & 0 & 0 \\
26-Apr & Gold Mine Creek and Stevens Reach 6 & 3 & 0 \\
6-May & Unnamed Tributary and Stevens Reach 3 & 0 & 0
\end{tabular}

Breeding migrations. - In 2019, I observed a total of 954 T. rivularis, including four amplexing pairs and groups, across nine survey dates between 16 March 2019 and 12 May 2019 in both Stevens Creek Reach 4 and Twitty Creek (Table 2), although many individuals may have been captured more than once. I captured and measured 80 adult males, (mean $\mathrm{SVL}=68.6 \mathrm{~mm} \pm 0.5 \mathrm{~mm}$; range, $55-76 \mathrm{~mm}$ ) and eight juveniles (mean $\mathrm{SVL}=28.0 \mathrm{~mm} \pm 1.4 \mathrm{~mm}$; range, $23-35 \mathrm{~mm}$ ). All adult $T$. rivularis captured were confirmed to be males with the exception of three amplexing pairs and an amplexing group of three on 14 April 2019 in which sex was not assessed due to permit requirements. It is likely that at least one individual in an amplexing pair/group was a female.

In Stevens Creek Reach 4, observations of T. rivularis increased to a peak of 373 observed individuals on 24 March 2019 and fell to 92 observations four weeks later on 27 
April 2019 (Table 2). T. granulosa and T. torosa numbers in Stevens Creek were lower than $T$. rivularis, and peak encounter timing was later. T. granulosa detections increased steadily from one observation on 16 March 2019 to 74 observations on 12 May 2019 (Table 2). I first observed three T. torosa individuals on 13 March 2019 and numbers increased to 23 individuals on 27 April 2019 (Table 2).

Table 2. Count Data for Each Species Observed During Each Survey Date in 2019

\begin{tabular}{ccccccc} 
Location & Date & $\begin{array}{c}\text { Taricha } \\
\text { rivularis }\end{array}$ & $\begin{array}{c}\text { Taricha } \\
\text { torosa }\end{array}$ & $\begin{array}{c}\text { Taricha } \\
\text { granulosa }\end{array}$ & $\begin{array}{c}\text { T.torosal } \\
\text { granulosa }\end{array}$ & $\begin{array}{c}\text { Dicamptodon } \\
\text { ensatus }\end{array}$ \\
\hline Stevens & 16 Mar 19 & 84 & 0 & 1 & 0 & 0 \\
Creek & 24 Mar 19 & 373 & 3 & 4 & 2 & 0 \\
& 14 Apr 19 & 343 & 6 & 49 & 6 & 0 \\
& 27 Apr 19 & 92 & 23 & 45 & 18 & 2 \\
& 12 May 19 & 0 & 18 & 74 & 10 & 1 \\
Twitty & 17 Mar 19 & 13 & 1 & 8 & 22 & 2 \\
Creek & 3 Apr 19 & 29 & 51 & 53 & 3 & 4 \\
& 23 Apr 19 & 17 & 48 & 103 & 13 & 21 \\
& 11 May 19 & 3 & 52 & 58 & 7 & 17
\end{tabular}

In the Twitty Creek surveys, $T$. rivularis numbers were much smaller than on Stevens Creek (Table 2). The initial Twitty Creek observations peaked at 29 individual observations (26 adult males and 3 juveniles) on 3 April 2019 and then decreased to 17 adult males on 23 April 2019 ending the season at three individuals ( 1 male and 2 juveniles) on 11 May 2019. T. granulosa and T. torosa observations, in contrast, were more abundant in Twitty Creek compared to Stevens Creek (Table 2).

Breeding aggregation.-Using observations from all dates sampled, the southern $T$. rivularis population displayed clustered distributions in both Stevens $(N N R=0.22 ; Z=-$ 
42.29, $P<0.01)$ and Twitty $(N N R=0.45 ; Z=-7.95 ; P<0.01)$ Creeks, although the overall number of detections was smaller in Twitty.

The nearest neighbor analyses by sampling date for Stevens Creek in particular showed consistently clustered distributions throughout the season: on 24 March 2019, the $N N R$ was $0.19(Z=-29.81 ; P<0.01)$, on 14 April 2019 , the $N N R$ was $0.24(Z=-27.03 ; P$ $<0.01)$, and on 27 April 2019, the $N N R$ was $0.40(Z=-11.05 ; P<0.01)$. In Twitty Creek, however, distributions initially alternated between randomly distributed across the landscape (17 March 2019: $N N R=1.14 ; \mathrm{z}=0.95 ; P=0.34$ and 24 April 2019: $N N R=$ 1.13; $Z=1.05 ; P=0.29$ ) and clustered (3 April 2019: $N N R=0.58 ; Z=-4.34 ; P<0.01$ ), but remaining individuals were ultimately over-dispersed by the end of the season (11 May 2019: $N N R=6.37 ; Z=17.78 ; P<0.01$ ) in Twitty Creek (Table 3).

Habitat use and availability. - Available habitat in Stevens Creek differed detectably from habitat in Twitty Creek $\left(\chi^{2}=29.87, \mathrm{df}=4, P<0.001\right)$. The first $223 \mathrm{~m}$ of the Stevens Creek reach consisted of cascades separated by runs and pools. The habitat upstream of the cascades was sinuous flat-water runs, separated by pools and riffles. The mean width of the aquatic habitat within the Stevens Creek reach was $3.6 \mathrm{~m}(1.52 \mathrm{~m}$ to $8.66 \mathrm{~m})$. The most available mesohabitat within the Stevens Creek reach was run or flatwater (566 m; 56.7\%). Pools comprised $167.2 \mathrm{~m}(16.7 \%)$ of available habitat, with a mean depth of $0.63 \mathrm{~m}$ ( 0.40 to $1.01 \mathrm{~m})$. Riffles or turbulent water $(144.1 \mathrm{~m} ; 14.4 \%)$ were the next most abundant habitats available, followed by high gradient turbulent water or cascades (121.6 m; 12.2\%). 
Table 3. Average Nearest Neighbor Analysis.

\begin{tabular}{|c|c|c|c|c|c|c|c|c|c|}
\hline & \multicolumn{5}{|c|}{ Twitty } & \multicolumn{4}{|c|}{ Stevens } \\
\hline & All Dates & 17-Mar & 3-Apr & 24-Apr & 11-May & All Dates & 24-Mar & 14-Apr & 27-Apr \\
\hline Observed Mean Distance & 12.41 & 43.08 & 44.06 & 18.48 & 247.83 & 1.50 & 1.41 & 2.36 & 4.83 \\
\hline Expected Mean Distance & 27.32 & 37.86 & 76.14 & 16.31 & 38.93 & 6.73 & 7.31 & 9.96 & 12.12 \\
\hline Nearest Neighbor Ratio & $0.45 *$ & $1.14^{\S}$ & $0.58 *$ & $1.13^{\S}$ & $6.37^{¥}$ & $0.22 *$ & $0.19 *$ & $0.24 *$ & $0.40 *$ \\
\hline$z$-score & -7.95 & 0.95 & -4.34 & 1.05 & 17.78 & -42.29 & -29.81 & -27.03 & -11.05 \\
\hline$P$ & $0.00 *$ & $0.34^{\S}$ & $0.00 *$ & $0.29 \S$ & $0.00^{¥}$ & $0.00 *$ & $0.00 *$ & $0.00 *$ & $0.00 *$ \\
\hline
\end{tabular}

Note: $\S=$ Non-significant $(P>0.05)$; accept the null hypothesis; random distribution. * $=$ Significant $(P<0.05)$ and NNR $>$ 1.0 , clustered distribution. $¥=$ Significant $(P<0.05)$ and NNR $<1.0$, dispersed distribution. 
The aquatic habitat within Twitty Creek averaged $1.82 \mathrm{~m}$ in width, ranging from a minimum of $0.82 \mathrm{~m}$ to a maximum of $9.54 \mathrm{~m}$. The most abundant mesohabitat was again run or flatwater $(488.7 \mathrm{~m} ; 56.5 \%)$, but in Twitty Creek, riffles or turbulent water were the next most abundant habitat available (208.9 m; 24.1\%). Pools comprised $138.3 \mathrm{~m}$ or $16.0 \%$ of available habitat with a mean depth of $0.40 \mathrm{~m}$ and ranging from $0.67 \mathrm{~m}$ to 0.27 $m$ in depth. High-gradient turbulent water or cascades were not present, but Twitty Creek also had a large $(18.8 \mathrm{~m}) \log$ jam present within the creek representing $2.2 \%$ of the available instream habitat.

In Stevens Creek, available habitat and habitat use by each Taricha newt differed significantly $\left(\chi^{2}=48.234, \mathrm{df}=6, P<0.05\right)$. Within Stevens Creek, flatwater runs were the most common mesohabitat used by T. rivularis (Table 4). Pools were the next most common mesohabitat used, followed by riffles. T. granulosa and T. torosa, in contrast, were most commonly observed in pools, followed by runs and riffles (Table 4).

Table 4. Count of Mesohabitat Use by Each Species Encountered

\begin{tabular}{llccccc} 
Location & $\begin{array}{l}\text { Mesohabitat } \\
\text { Type }\end{array}$ & $\begin{array}{l}\text { Taricha } \\
\text { rivularis }\end{array}$ & $\begin{array}{c}\text { Taricha } \\
\text { torosa }\end{array}$ & $\begin{array}{c}\text { Taricha } \\
\text { granulosa }\end{array}$ & $\begin{array}{c}\text { T. torosal } \\
\text { granulosa }\end{array}$ & $\begin{array}{c}\text { Dicamptodon } \\
\text { ensatus }\end{array}$ \\
\hline Stevens & bank & 47 & 2 & 10 & 0 & 0 \\
& cascade & 1 & 0 & 1 & 0 & 0 \\
& pool & 290 & 33 & 85 & 29 & 2 \\
& riffle & 164 & 0 & 12 & 0 & 0 \\
& run & 389 & 15 & 65 & 7 & 1 \\
\hline \multirow{3}{*}{ Twitty } & bank & 31 & 66 & 68 & 24 & 1 \\
& pool & 11 & 33 & 75 & 13 & 27 \\
& riffle & 6 & 5 & 6 & 0 & 1 \\
& run & 10 & 48 & 73 & 7 & 14
\end{tabular}


In Twitty Creek, I observed T. rivularis most commonly on the bank (31 individuals, 53.4\%), not in-stream (Table 4). T. granulosa and T. torosa were observed in greater numbers in Twitty Creek compared to T. rivularis, but, similarly, in Twitty Creek, over a third of the observed T. granulosa and T. torosa were on the bank. For in-stream Twitty Creek habitat, $T$. rivularis was most commonly found in pools and runs, similar to $T$. granulosa and T. torosa (Table 4).

I found a total of six variables to be predictive of male T. rivularis and T. granulosa habitat use in the final selected model of the binary logistic regression. Both Riffle ( $(=-$ 1.86, SE $0.35, P<0.05)$ and Run $(\beta=-0.61$, SE $0.19, P<0.05)$ mesohabitats were associated more with T. rivularis than Pool (Table 5). For nearest cover type, T. rivularis tended to be associated more with Water Depth compared to the reference category of Interstitial Spaces, but the relationship was statistically weak $(\beta=-0.60$, SE $0.32, p<$ 0.06). T. granulosa was more strongly associated with Woody Debris $(B=0.48$, SE 0.24 , $P=0.04)$ and Undercut $(\beta=0.71, \mathrm{SE} 0.22, P<0.05)$ than with Interstitial Spaces. For substrate, $T$. granulosa was more strongly associated with Cobble $(\beta=2.29$, SE 1.05, $P=$ $0.03)$ and Silt or Organic Matter $(B=2.30$, SE 0.1.05, $P=0.03)$ than with the reference category of Boulders (Table 5). 
Table 5. Binary Logistic Regression Results for Habitat Use

\begin{tabular}{|c|c|c|c|c|c|c|c|}
\hline & & & & & & \multicolumn{2}{|c|}{ Confidence Interval } \\
\hline & $\beta$ & SE & Z & $P$ & OR & & $97.50 \%$ \\
\hline (Intercept) & -2.80 & 1.04 & -2.70 & $0.01 *$ & 0.06 & 0.00 & 0.30 \\
\hline Mesohabitat: riffle & -1.86 & 0.35 & -5.33 & $<0.05^{* *}$ & 0.16 & 0.07 & 0.30 \\
\hline Mesohabitat: run & -0.61 & 0.19 & -3.21 & $<0.05^{* *}$ & 0.54 & 0.37 & 0.79 \\
\hline Substrate: cobble & 2.29 & 1.05 & 2.18 & $0.03 * *$ & 3.61 & 0.71 & 65.92 \\
\hline Substrate: gravel & 1.28 & 1.04 & 1.23 & 0.22 & 9.88 & 1.89 & 182.43 \\
\hline Substrate: S/O & 2.30 & 1.05 & 2.19 & $0.03 * *$ & 10.01 & 1.91 & 184.67 \\
\hline Substrate: sand & 1.69 & 1.04 & 1.63 & 0.10 & 5.45 & 1.07 & 99.50 \\
\hline Cover: OM/veg & 0.52 & 0.31 & 1.70 & 0.09 & 1.69 & 0.91 & 3.04 \\
\hline Cover: undercut & 0.71 & 0.22 & 3.27 & $<0.05^{* *}$ & 2.04 & 1.33 & 3.14 \\
\hline Cover: water depth & -0.60 & 0.32 & -1.87 & $0.06^{*}$ & 0.55 & 0.28 & 1.00 \\
\hline Cover: woody debris & 0.48 & 0.24 & 2.01 & $0.04 * *$ & 1.62 & 1.01 & 2.60 \\
\hline
\end{tabular}

Note: Reference category for mesohabitat was pool. Reference category for substrate was boulder. Reference category for cover type was interstitial spaces. $\beta=$ coefficient; $\mathrm{SE}=$ Standard Error; $\mathrm{Z}=$ the Wald's Test statistic (standard deviations); $\mathrm{OR}=$ odds ratio or the exponent of $\beta$. The $(+)$ denotes a positive association with $T$. rivularis and $(-)$ denotes negative association with $T$. rivularis.

Oviposition site selection. - I detected a total of 58 T. rivularis egg masses across 17

oviposition sites in Stevens Creek Reach 4 (Table 6). I observed 61\% of oviposition sites in runs, $22 \%$ in riffles, and $17 \%$ in pools. The mean attached-substrate size was $1.52 \mathrm{~m}^{3}$ (range, 0.22-11.68), and the attached substrates were either classified as a boulder (50\%) or cobble (44\%), with one oviposition site on a large piece of wood containing 13 egg masses. Ten of the 17 oviposition sites, representing 39 of the 58 egg masses (67\%), were located in one $30 \mathrm{~m}$ section of Stevens Creek. 
Table 6. Oviposition Site Characteristics and Measurements

\begin{tabular}{lccc} 
& Mean & Min & Max \\
\hline Number egg masses per oviposition site & 3.41 & 1.00 & 13.00 \\
Attached Substrate Size $\left(\mathrm{m}^{2}\right)$ & 1.52 & 0.22 & 11.68 \\
Depth $(\mathrm{m})$ & 0.16 & 0.03 & 0.30 \\
Distance from Bank $(\mathrm{m})$ & 1.12 & 0.24 & 2.44 \\
Canopy Cover $(\%)$ & 85.62 & 68.80 & 100.00
\end{tabular}

Binary logistic regression revealed that each unit increase of substrate size increased the probability of egg mass presence on a substrate by $40 \%(\beta=2.68$, SE 1.33 , $P=0.04 ; \mathrm{W}=75, \mathrm{p}=0.017)($ Table 7, Figure 4$)$.

Table 7. Binary Logistic Regression Results for Oviposition Site Selection.

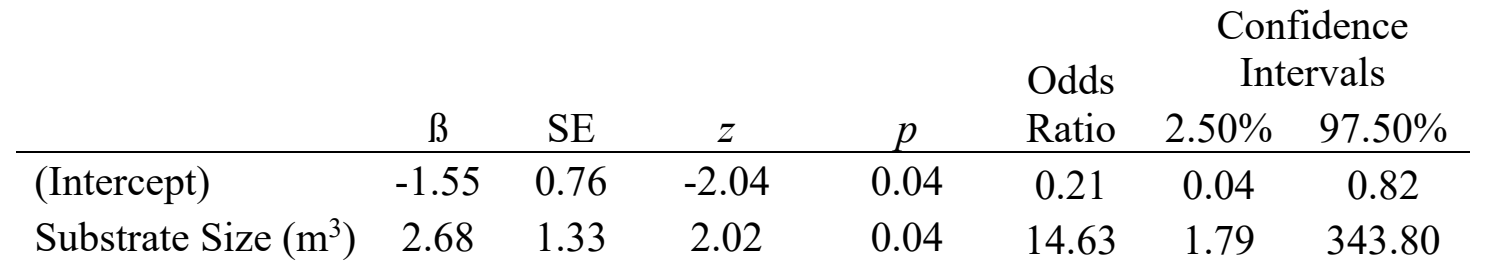

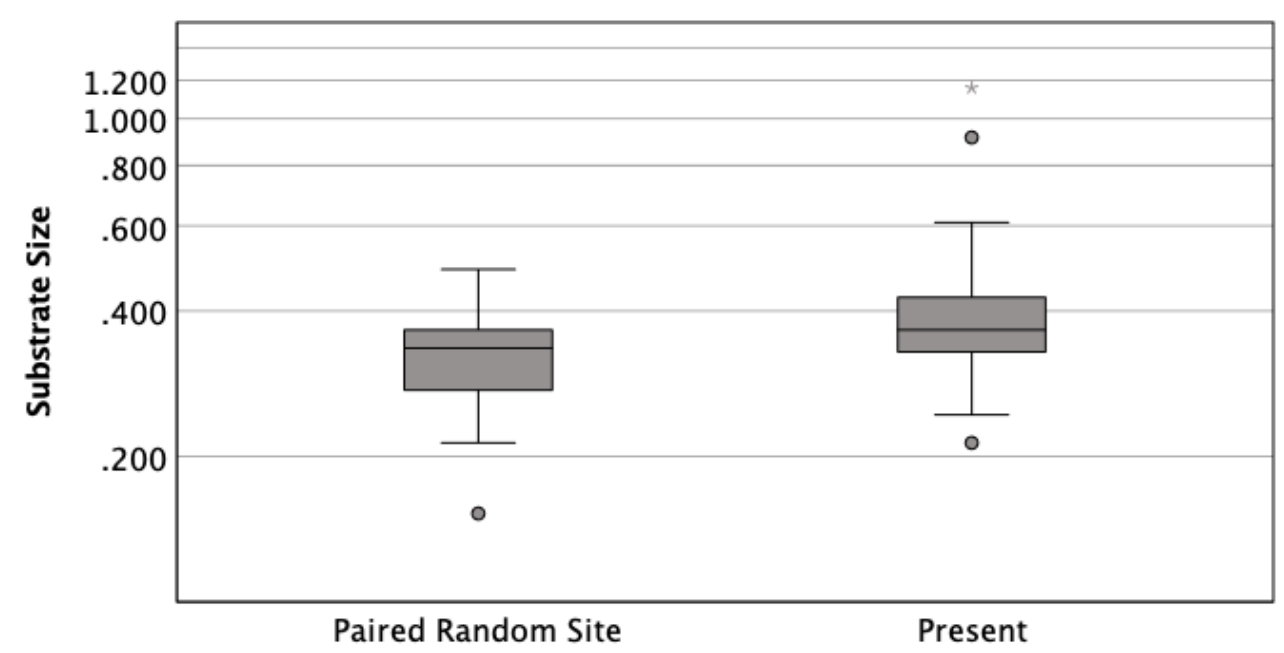

Figure 4. Oviposition site substrate size in comparison to paired random unoccupied sites on a $\log$ scale. 


\section{DiscuSSION}

Range of southern population.-The southern population of T. rivularis was discovered in 2009 (Reilly et al. 2014) in the Upper Stevens Creek watershed, but until 2018, no surveys had been conducted in the surrounding watersheds to determine the extent of the range of this population. Based on our surveys from the winter and spring of 2018, the population aggregates in a $1000 \mathrm{~m}$ section of Stevens Creek and Twitty Creek. To the west of Stevens Creek and in the adjacent watersheds, surveys were conducted in Lambert Creek and its tributaries once. These surveys did not confirm the absence of $T$. rivularis in these streams. More surveys need to be conducted to confirm the presence or absence of T. rivularis in these adjacent watersheds and streams especially in areas of redwood forests where the species is generally found (Packer 1960; Reilly et al. 2014).

Surveys of the tributaries to the east of Stevens Creek were all short distances upstream due to the steep incline and heavy vegetation overgrowth. In addition, those streams all had calcified deposits on the stream channel with a lack of boulder and cobble substrate and any substantial flow which makes the tributaries to the east of Stevens Creek unsuitable for breeding T. rivularis (Twitty 1942; Twitty 1966). Other than Twitty Creek, one other tributary was surveyed to the west of Stevens Creek, the unnamed tributary $200 \mathrm{~m}$ south of the Twitty-Stevens confluence. I observed one T. rivularis individual on the bank on 16 April 2018. This observation was two days before Stevens Creek Reach 4 survey when $T$. rivularis individuals were already dispersing at the end of 
the breeding season. The presence of just one individual on the bank of the creek during the out-migration suggests that this observation was of a dispersing individual.

Breeding movements. - The Pepperwood Creek experiments conducted by Victor Twitty and others in Sonoma County concluded that breeding adult T. rivularis individuals begin moving towards breeding locations in late January and arrive in the stream once the spring rains begin to subside (Packer 1960; Packer 1963; Twitty 1966; Twitty et al. 1966). The breeding pattern of the southern population suggests a similar breeding period that starts in mid-March and abruptly ends in late-April.

The 2019 breeding surveys described an obvious change in magnitude of breeding migration into and out of the creeks. Due to multiple storms in early March, surveys began on 16 March 2019 and a large number of males were already present in Stevens Creek Reach 4 during the initial survey. The following surveys and the obvious aggregation of breeding males in Stevens Creek followed by the abrupt end six weeks later provided a general migratory breeding pattern. During the 27 April 2019 survey, I observed many individuals still within the stream moving toward shore and attempting to climb up near-vertical banks. This behavior indicated that many individuals still present in the channel were finished breeding and dispersing upland.

This breeding migration pattern is similar to what was described in the Pepperwood Creek experiments; breeding began in March and abruptly ended mid-to-late-April. Males typically arrived a few weeks before the females and females were only present for a few days (Davis and Twitty 1964). In another population studied by Twitty, breeding 
occurred in April, indicating some phenotypic plasticity in breeding patterns (Twitty 1942; Packer 1960; Twitty 1966; Petranka 2010).

This phenotypic plasticity in breeding patterns was also observed in the southern population. During the initial survey of Stevens Creek Reach 4 on 18 April 2018, I observed 68 T. rivularis individuals. The following year, around the same time on 14 April 2019, I observed 343 T. rivularis individuals just below its peak. It was not until 27 April 2019 that T. rivularis numbers were at mid-April 2018 numbers indicating that the breeding season ended about two weeks later in 2019 compared to 2018. The later end (or later start) to the 2019 breeding season could result from the heavy storms in early March. Packer (1960) found heavy rainfall heavily influenced and inhibited movement toward the stream in the Pepperwood Creek population. In addition, rainfall is also the primary influence on movement out of the water during the breeding season and at the end of the breeding season (Packer 1960).

Habitat partitioning.-In Mendocino County, where T. rivularis, T. granulosa, and T. torosa co-occur, many observations were made by Victor Twitty (1942) that $T$. granulosa and T. rivularis would enter streams at the same time. In Stevens Creek Reach 4, $T$. rivularis had entered the stream before and in a much greater magnitude than $T$. granulosa. Additionally, in Mendocino County, both T. rivularis and T. granulosa would breed in different stream microhabitats. T. torosa, on the other hand, was present in neighboring systems, but was not present in the same stream that $T$. rivularis and $T$. granulosa were breeding in (Twitty 1942). The exclusion of T. torosa by T. granulosa has been documented in other parts of its range (AmphibiaWeb. 2021. Taricha granulosa. 
Available from https://amphibiaweb.org/species/4288 [Accessed 5 July 2021]). Based on the numbers of T. granulosa and T. torosa in Stevens Creek Reach 4, fewer T. toros $a$ were in the stream than T. granulosa. I did not observe any amplexing pairs or groups or other breeding behaviors of either T. granulosa or T. torosa during the 2019 surveys. This suggests that surveys did not extend far enough into the breeding season, as both $T$. granulosa and T. torosa typically breed until June. However, in the San Francisco Bay Area, $T$. torosa have not been observed breeding after April, and $T$. granulosa breeding usually ends even earlier (David Wake, pers. comm.). Alternately, both T. granulosa and T. torosa may be just passing through Stevens Creek on their way to the multitude of ponds within the watershed or to slower segments of Steven Creek. Many of the ponds in the watershed are sag ponds formed between the active fault zones. Sag ponds are ideal for breeding for T. torosa and T. granulosa, with clear and deep water year-round.

Available habitat.-Both Twitty Creek and Stevens Creek are in the same watershed and are relatively similar in terms of mesohabitat availability. The biggest difference between the 2 streams is that Stevens Creek Reach 4 contains approximately $200 \mathrm{~m}$ of fast-flowing cascades while Twitty Creek does not. The dimensions of the stream, however, are much different. Stevens Creek Reach 4 is almost twice as wide as Twitty Creek which may affect breeding success as narrower streams have more erratic flows, especially during storms. Erratic flows could potentially cause larvae or egg masses to wash out or be destroyed if high-energy flows cause the movement of large rocks and 
other material. With a broader channel, Stevens Creek has an area with flood plains which provides more room for storm flows to spread out (Rosgen 1994).

The presence of complex habitat features of Stevens Creek most likely affected the reproductive success of $T$. rivularis throughout the years. Complex habitat features are known to be beneficial to many species, including but not limited to salmonids (Beechie et al. 2005; Solazzi et al. 2011), frogs (Lind et al. 1996; Fellers and Kleeman 2007), and invertebrate food sources (Gregory et al. 1991). I observed rainbow trout and multiple invertebrate species during surveys.

Twitty Creek or Stevens Creek. - Surveys and analysis of the distribution of $T$. rivularis in both Stevens Creek Reach 4 and Twitty Creek suggest that Stevens Creek Reach 4 and not Twitty Creek is where T. rivularis are aggregating for breeding. The presence of egg masses only in Stevens Creek suggests that the southern population of $T$. rivularis is only breeding in Stevens Creek Reach 4. Finally, the presence of juveniles only in Twitty Creek suggests that Twitty Creek may only be in the path of dispersing juveniles after transformation (Twitty et al. 1967; Petranka 2010). I did not observe any juvenile T. rivularis in Stevens Creek Reach 4. Additional surveys and monitoring of this population are needed to confirm this assumption.

Adult male habitat use.-The general habitat of T. rivularis is simply described by Victor Twitty (1955) as mountain brooks or clean and rocky streams with moderately fast flows. The southern population of $T$. rivularis has a greater association with the fasterflowing mesohabitats (riffle and run) of the stream when compared to pool habitats. Additionally, T. rivularis was more associated with water depth cover types over the 
interstitial spaces of boulders and rocks. T. rivularis may thus prefer to use riffle and run habitat with near deep pools for cover.

Taricha granulosa and T. torosa general breeding habitat is described as ponds, lakes, or slow-flowing water of streams (Petranka 2010). The T. granulosa and T. torosa population co-existing with the southern population of $T$. rivularis exhibit similar habitat preferences and are more likely to be found in habitats with silty substrate, generally found in pools and near undercut and woody debris cover types that are often in areas with slow-flowing water. In southern California, however, T. torosa uses rapidly flowing streams for breeding, and egg masses have been observed in runs and riffles (Gamradt and Kats 1997)

Female oviposition site selection.-For egg mass placement, or oviposition site selection, females deposit egg masses on the bottoms of large rocks within fast flowing waters (Davis and Twitty 1964; Twitty 1966). The majority (67\%) of observed oviposition sites and egg masses occurred in an area where high densities of adults were observed. Even with a small sample size, large substrate is the only habitat parameter that appears to influence the probability of a female T. rivularis choosing a site to deposit her eggs. Other habitat parameters such as water speed, canopy cover, depth, and distance from bank could also influence the decision of the female T. rivularis; however, more data is needed to confirm this hypothesis.

The availability of large substrates in well-oxygenated water is considered necessary for reproductive success of $T$. rivularis (Twitty 1942; Twitty 1966). These habitats can be affected by multiple factors, including timber harvest (Riley et al., 2005; Welsh \& 
Ollivier, 1998), agriculture (Blann et al. 2009), and urbanization (Welsh and Ollivier 1998; Riley et al. 2005), which can increased sediment inputs into the stream (Gamradt and Kats 1997; Kerby and Kats 1998). Increased sediment inputs alter flow regimes and the habitat and food sources for breeding T. rivularis.

Management implications. - The Upper Stevens Creek watershed is a relatively well-protected swath of land surrounded by MROSD parks and properties. The only disturbance to the Stevens Creek channel is the few hiking and mountain biking creek crossings. Unfortunately, many of the northern populations are not well protected. Much of the northern populations' habitat is becoming urbanized with buildings and roads or affected by agricultural practices.

The timing of breeding migration of $T$. rivularis could have implications for managers during the breeding seasons. Depending on the location of migratory barriers such as highly trafficked roads and trails, specific management practices may need to be put in place. For example, Tilden Regional Park of East Bay Regional Parks District (EBRPD) implement road closures of roads in the path of migrating T. granulosa and $T$. torosa (EBRPD. 2019. Newt Migration Closes South Park Drive in Tilden Regional Park. Available from $\underline{\text { https://www.ebparks.org/civica/press/display.asp? layout=11\&Entry=540 }}$ [Accessed 5 July 2021]). Similarly, Peninsula Open Space Trust and MROSD are conducting a newt mortality and population study in Santa Clara County, where over 11,000 newt mortalities have been documented since 2017 (MROSD. 2020. Agenda Item 6. https://www.open space.org/sites/default/files/20200923_Agmt_Newt MortalityPopulationStudyAlmaBridgeRd_R-20-104.pdf [Accessed 5 July 2021]). 
Threats to the southern population of $\mathrm{T}$. rivularis.- The most recent threat to the southern population of $T$. rivularis was an event intensified by climate change. The CZU Lightning Complex fire of 2020 burned 86,509 acres in the Santa Cruz Mountains and was stopped at Pescadero Creek, approximately $10 \mathrm{~km}$ away from the Stevens Creek watershed. Additional surveys in these areas are still needed to assess whether the southern population of $T$. rivularis extends further west to evaluate the effects of the CZU fire on the adjacent watersheds and their inhabitants. 


\section{Literature Cited}

Alford, R.A., and S.J. Richards. 1999. Global Amphibian Declines: A problem in applied ecology. Annual Review of Ecology and Systematics, 30:133-165.

Ashton, D., S. Marks, and H. Welsh. 2006. Evidence of continued effects from timber harvesting on lotic amphibians in redwood forests of northwestern California, 221:183193.

Baker, J.M.R., and V. Waights. 1994. The effects of nitrate on tadpoles of the tree frog (Litoria caerulea). Herpetological Journal 3:106-108.

Beebee, T.J.C. 1995. Amphibian breeding and climate. Nature, 374:219-220.

Beechie, T.J., M. Liermann, E.M. Beamer, and R. Henderson. 2005. A classification of habitat types in a large river and their use by juvenile salmonids. Transactions of the American Fisheries Society 134:717-729

Best, M.L., and H.H. Welsh. 2014. The trophic role of a forest salamander: Impacts on invertebrates, leaf litter retention, and the humification process. Ecosphere 5:Article 16.

Bishop, P.J., Angulo, A., Lewis, J. P., Moore, R. D., Rabb, G. B., and Moreno, J. G. 2012. The amphibian extinction crisis-What will it take to put the action into the amphibian conservation action plan? S.A.P.I.EN.S. Surveys and Perspectives Integrating Environment and Society 5:97-111

Blann, K.L., J.L. Anderson, G.R. Sands and B. Vondracek. 2009. Effects of agricultural drainage on aquatic ecosystems: a review. Critical Reviews in Environmental Science and Technology 39:909-1001.

Bohonak, A.J., and H.H. Whiteman 1999. Dispersal of the fairy shrimp Branchinecta coloradensis (Anostraca): Effects of hydroperiod and salamanders. Limnology and Oceanography 44:487-493.

Brode, J.M., and R.B. Bury. 1984. California Riparian Systems: Ecology, Conservation, and Productive Management. University of California Press, Berkeley, California, USA.

Brodie, E.D. 1968. Investigations on the skin toxin of the adult Rough-skinned Newt, Taricha granulosa. Copeia 1968:307-313.

Brodman, R., J. Ogger, T. Bogard, A.J. Long, R.A. Pulver, K. Mancuso, and D. Falk. 2003. Multivariate analyses of the influences of water chemistry and habitat parameters on the abundances of pond-breeding amphibians. Journal of Freshwater Ecology 18:425-436. 
Brown, D.D., and L. Cai. 2007. Amphibian metamorphosis. Developmental Biology, 306, 20-33.

Burke, J.N., C.M. Bergeron, B.D. Todd, and W.A. Hopkins. 2010. Effects of mercury on behavior and performance of northern Two-lined Salamanders (Eurycea bislineata). Environmental Pollution 158:3546-3551.

Burnham, K.P., and D.R. Anderson. 2002. Model Selection and Multimodel Inference: A Practical Information-Theoretic Approach $2^{\text {nd }}$ Edition. Springer-Verlag, New York, New York, USA.

Burton, T.M., and G.E. Likens.1975. Energy flow and nutrient cycling in salamander populations in the Hubbard Brook Experimental Forest, New Hampshire. Ecology 56, 1068-1080.

Bury, R.B. 1968. The distribution of Ascaphus truei in California. Herpetologica 24:3946.

Bury, R.B., and P.S. Corn. 1991. Sampling methods for amphibians in streams in the Pacific Northwest. U.S. Department of Agriculture, Forest Service, Pacific Northwest Research Station 275:1-29.

Carey, C., and M.A. Alexander. 2003. Climate change and amphibian declines: Is there a link? Diversity and Distributions 9:111-121.

Carey, C., P.S. Corn, M.S. Jones, L.J. Livo, E. Muths, and C.W. Loeffler. 2005. Factors limiting the recovery of boreal toads (Bufo b. Boreas). 222-236 In Amphibian Declines: The Conservation Status of United States Species. Lannoo, M. (Ed.). University of California Press, Berkley, California, USA

Carr, L.W., and L. Fahrig. 2001. Effect of road traffic on two amphibian species of differing vagility. Conservation Biology 15:1071-1078.

Corn, P. 2005. Climate change and amphibians. Animal Biodiversity and Conservation 28:59-67.

Corn, P., and R. Bury. 1989. Logging in western Oregon: Responses of headwater habitats and stream amphibians. Forest Ecology and Management 29: 39-57.

Costanza, R., R. d'Arge, R. de Groot, S. Farber, M. Grasso, B. Hannon, K. Limburg, S. Naeem, R.V. O'Neill, et al. 1997. The value of the world's ecosystem services and natural capital. Nature 387:253-260.

Davic, R.D. 1991. Ontogenetic shift in diet of Desmognathus quadramaculatus. Journal of Herpetology 25:108-111. 
Davic, R.D., and H.H. Welsh. 2004. On the ecological roles of salamanders. Annual Review of Ecology, Evolution, and Systematics 35:405-434.

Davidson, C., and R.A. Knapp. 2007. Multiple stressors and amphibian declines: Dual impacts of pesticides and fish on Yellow-legged Frogs. Ecological Applications 17:587-597.

Davidson, C., H. Bradley Shaffer, and M.R. Jennings. 2001. Declines of the California Red-legged Frog: Climate, Uv-B, habitat, and pesticides hypotheses. Ecological Applications 11:464-479.

Davis, W.C., and V. Twitty. 1964. Courtship behavior and reproductive isolation in the species of Taricha (Amphibia, Caudata). Copeia 1964:601-610.

Dodd, C. K. (Ed.). (2010). Amphibian Ecology and Conservation: A handbook of techniques. Oxford University Press. Oxford, UK.

Donnelly, M.A., and M.L. Crump. 1998. Potential effects of climate change on two neotropical amphibian assemblages. Climatic Change 39:541-561.

Dudgeon, D., A.H. Arthington, M.O. Gessner, Z.I. Kawabata, D.J. Knowler, C. Lévêque, R.J. Naiman, A.H. Prieur-Richard, D. Soto, M.L.J. Stiassny, et al. 2006. Freshwater biodiversity: Importance, threats, status and conservation challenges. Biological Reviews 81:163-182.

Duellman, W.E., and L. Trueb, 1994. Biology of amphibians. John Hopkins University Press, Baltimore, Maryland, USA.

DuRant, S.E., and W.A. Hopkins. 2008. Amphibian predation on larval mosquitoes. Canadian Journal of Zoology 86:1159-1164.

Fellers, G.M., and P.M. Kleeman. 2007. California Red-legged Frog (Rana Draytonii) movement and habitat use: Implications for conservation. Journal of Herpetology 41:276-286.

Gamradt, S.C., and L.B. Kats. 1996. Effect of introduced crayfish and mosquitofish on California Newts. Conservation Biology 10:1155-1162.

Gamradt, S.C., and L.B. Kats. 1997. Impact of chaparral wildfire-induced dedimentation on oviposition of stream-breeding California Newts (Taricha torosa). Oecologia 110:546-549.

Garber, D.P., and C.E. Garber. 1978. A variant form of Taricha granulosa (Amphibia, Urodela, Salamandridae) from Northwestern California. Journal of Herpetology 12:5964. 
Gibbs, J.P., and W.G. Shriver. 2005. Can road mortality limit populations of poolbreeding amphibians? Wetlands Ecology and Management 13: 281-289.

Grant, D., O. Anderson, and V. Twitty. 1968. Homing orientation by olfaction in newts (Taricha rivularis). Science 160:1354-1356.

Grant, E.H.C., E.L. Muths, R.A. Katz, S. Canessa, M.J. Adams, J.R. Ballard, L. Berger, C.J. Briggs, J. Coleman, M.J. Gray, M. J., Harris, et al. 2016. Salamander chytrid fungus (Batrachochytrium salamandrivorans) in the United States-Developing research, monitoring, and management strategies. U.S. Geological Survey Open-File Report 2015-1233. 26 p.

Gregory, S.V., F.J. Swanson, W.A. McKee, and K.W. Cummins. 1991. An ecosystem perspective of riparian zones. BioScience 41:540-551.

Gupta, S. (2016). Animal models: Unlock your inner salamander. Nature 540:S58-S59.

Hague, M.T.J., L.A. Avila, C.T. Hanifin, W.A. Snedden, A.N. Stokes, E.D. Brodie, and E.D. Brodie. 2016. Toxicity and population structure of the Rough-skinned Newt (Taricha granulosa) outside the range of an arms race with resistant predators. Ecology and Evolution 6:2714-2724.

Hairston, N.G. 1996. Zooplankton egg banks as biotic reservoirs in changing environments. Limnology and Oceanography 41:1087-1092.

Hanifin, C.T. 2010. The chemical and evolutionary ecology of tetrodotoxin (TTX) toxicity in terrestrial vertebrates. Marine Drugs 8:577-593.

Hardin, G. 1960. The competitive exclusion principle. Science 131: 1292-1297.

Hawkins, C.P., J.L. Kershner, P.A. Bisson, M.D. Bryant, S.V. Gregory, D.A. McCullough C.K. Overton, G.H. Reeves, R.J. Steedman, and M.K.Young. 1993. A hierarchical approach to classifying stream habitat features. Fisheries 18:3-12.

Hedgecock, D. 1978. Population subdivision and genetic divergence in the Red-bellied Newt, Taricha rivularis. Evolution 32:271-286.

Hocking, D.J., and K.J. Babbitt. 2014. Amphibian contributions to ecosystem services. Herpetological Conservation and Biology, 9:1-17.

Innes, R.J., D.H. Van Vuren, D.A. Kelt, M.L. Johnson, J.A. Wilson, and P.A. Stine. 2007. Habitat associations of Dusky-footed Woodrats (Neotoma fuscipes) in mixedconifer forest of the Northern Sierra Nevada. Journal of Mammalogy 88:1523-1531. 
Jackson, C.R., C.A. Sturm, and J.M. Ward. 2001. Timber harvest impacts on small headwater stream channels in the coast ranges of Washington. Journal of the American Water Resources Association 37:1533-1549.

Kamil, B. (2020). MuMIn: multi-model inference. R package version 1.43.17. https://CRAN.R-project.org/package=MuMIn

Kerby, J.L., and L.B. Kats. 1998. Modified interactions between salamander life stages caused by wildfire-induced sedimentation. Ecology 79:740-745.

Kuchta, S., and A.M Tan. 2006. Limited genetic variation across the range of the Redbellied Newt, Taricha rivularis. Journal of Herpetology 40:561-565.

Lago, J., L.P. Rodríguez, L. Blanco, J.M. Vieites, and A.G. Cabado. 2015. Tetrodotoxin, an extremely potent marine neurotoxin: Distribution, toxicity, origin and therapeutical uses. Marine Drugs 13:6384-6406.

Lannoo, M. (Ed.). 2005. Amphibian Declines: The Conservation Status of United States Species. University of California Press, Berkeley, California, USA.

Leidy, R.A., G.S. Becker, and B.N. Harvey. 2005. Historical distribution and current status of steelhead/rainbow trout (Oncorhynchus mykiss) in streams of the San Francisco Estuary, California. Center for Ecosystem Management and Restoration, Oakland, CA.

Lesica, P., and F.W. Allendorf. 1995. When are peripheral populations valuable for conservation? Conservation Biology 9:753-760.

Licht, P., and A.G. Brown. 1967. Behavioral thermoregulation and its role in the ecology of the Red-bellied Newt, Taricha Rivularis. Ecology 48:598-611.

Lind, A.J., H. Welsh, and R.A. Wilson. 1996. The effects of a dam on breeding habitat and egg survival of the Foothill Yellow-legged Frog (Rana boylii) in Northwestern California. Herpetological Review 27:62-67.

Lowcock, L.A., and R.W. Murphy. 1990. Seed dispersal via amphibian vectors: Passive transport of Bur-marigold, Bidens cernua, achenes by migrating salamanders, genus Ambystoma. Canadian Field-Naturalist.

Marchetti, M., and A. Hayes. 2020. Life history variation in two populations of California Newt, Taricha torosa. Western North American Naturalis 80:165-174

Marsh, D.M., G.S. Milam, N.P. Gorham, and N.G. Beckman. 2005. Forest roads as partial barriers to terrestrial salamander movement. Conservation Biology 19:20042008 . 
Martel, A., A.S. Sluijs, M. Blooi, W. Bert, R. Ducatelle, M.C. Fisher, A. Woeltjes, W. Bosman, K. Chiers, F. Bossuyt, and F. Pasmans. 2013. Batrachochytrium salamandrivorans sp. nov. causes lethal chytridiomycosis in amphibians. Proceedings of the National Academy of Sciences 110:15325-15329.

Mitchell, A. 2005. The ESRI Guide to GIS Analysis, Volume 2: Spatial Measurements and Statistics. ${ }^{\text {st }}$ Edition. ESRI Press, Redlands, California, USA.

Morin, P. 1981. Predatory salamanders reverse the outcome of competition among three species of anuran tadpoles. Science 212:1284-1286

Mosher, H.S., F.A. Fuhrman, H.D. Buchwald, H.G. and Fischer. 1964. Tarichatoxintetrodotoxin: A potent neurotoxin. Science 144:1100-1110.

Neish, I.C. 1971. Comparison of size, structure, and distributional patterns of two salamander populations in Marion Lake, British Columbia. Journal of the Fisheries Board of Canada 28:49-58

Nussbaum, R.A., and E.D. Brodie. 1971. The taxonomic atatus of the Rough-skinned Newt, Taricha granulosa (Skilton), in the Rocky Mountains. Herpetologica 27:260 270 .

Oliver, M.G., and H.M. McCurdy. 1974. Migration, overwintering, and reproductive patterns of Taricha granulosa on southern Vancouver Island. Canadian Journal of Zoology 52:541-545.

Ortiz-Santaliestra, M.E., A. Marco, M.J. Fernández-Benéitez, and M. Lizana. 2007. Effects of ammonium nitrate exposure and water acidification on the Dwarf Newt: The protective effect of oviposition behaviour on embryonic survival. Aquatic Toxicology $85: 251-257$.

Packer, W.C. 1960. Bioclimatic influences on the breeding migration of Taricha Rivularis. Ecology, 41:509-517.

Packer, W.C. 1963. Observations on the breeding migration of Taricha rivularis. Copeia, 1963:378-382.

Peterman, W., J. Crawford, and R. Semlitsch. 2008. Productivity and significance of headwater streams: Population structure and biomass of the Black-bellied Salamander (Desmognathus quadramaculatus). Freshwater Biology 53:347-357.

Petranka, J.W. 1994. Response to impact of timber harvesting on salamanders. Conservation Biology 8:302-304. 
Petranka, J.W. 2010. Salamanders of the United States and Canada (Pbk. ed.). Smithsonian Books, Washington D.C., USA.

Petranka, J.W., and S.S. Murray. 2001. Effectiveness of removal sampling for determining salamander density and biomass: A case study in an Appalachian streamside community. Journal of Herpetology 35: 36-44.

Petranka, J.W., M.E. Eldridge, and K.E. Haley. 1993. Effects of timber harvesting on Southern Appalachian salamanders. Conservation Biology 7:363-370.

R Development Core Team. 2018. R: A language and environment for statistical computing. R Foundation for Statistical Computing, Vienna, Austria. http://www.Rproject.org.

Reilly, S., D. Portik, M. Koo, and D. Wake. 2014. Discovery of a new, disjunct population of a narrowly distributed salamander (Taricha rivularis) in California presents conservation challenges. Journal of Herpetology 48:371-379.

Riemer, W.J. 1958. Variation and systematic relationships with the salamander genus Taricha. University of California Press, Berkeley, California, USA.

Riley, S.P.D., H.B. Shaffer, S.R. Voss, and B.M. Fitzpatrick. 2003. Hybridization between a rare native tiger salamander (Abystoma californiense) and its introduced congener. Ecological Applications 13:1263-1275.

Riley, S.P.D., G.T. Busteed, L.B. Kats, T.L. Vandergon, L.F.S. Lee, R.G Dagit, J.L. Kerby, R.N. Fisher, and R.M. Sauvajot. 2005. Effects of urbanization on the distribution and abundance of amphibians and invasive species in Southern California streams. Conservation Biology 19:1894-1907.

Rosgen, D.L. 1994. A classification of natural rivers. CATENA 22:169-199.

Schneider, S. H., T.L. Root, and M.D. Mastrandrea. (Eds.). 2011. Encyclopedia of Climate and Weather ( $2^{\text {nd }}$ Ed.). Oxford University Press, Oxford, UK.

Schoener, T.W. 1974. Resource partitioning in ecological communities. Science 185:2739.

Secondi, J., V. Lepetz, G. Cossard, and S. Sourice. 2013. Nitrate affects courting and breathing but not escape performance in adult newts. Behavioral Ecology and Sociobiology 67:1757-1765.

Semlitsch, R.D. 1998. Biological delineation of terrestrial buffer zones for pond-breeding salamanders. Conservation Biology 12:1113-1119 
Sessions, S.K., and D.B. Wake. 2020. Forever young: Linking regeneration and genome size in salamanders. Developmental Dynamics 250:768-778

Simon, T.P., R. Jankowski, and C. Morris. 2000. Modification of an index of biotic integrity for assessing vernal ponds and small palustrine wetlands using fish, crayfish, and amphibian assemblages along southern Lake Michigan. Aquatic Ecosystem Health \& Management 3:407-418.

Solazzi, M.F., T.E. Nickelson, S.L. Johnson, and J.D. Rodgers. 2011. Effects of increasing winter rearing habitat on abundance of salmonids in two coastal Oregon streams. Canadian Journal of Fisheries and Aquatic Sciences 57:906-914

Song, F., B. Li, and D.L. Stocum. 2010. Amphibians as research models for regenerative medicine. Organogenesis 6:141-150.

Stebbins, R.C. 2003. A Peterson Field Guide to Western Reptiles and Amphibians. $3^{\text {rd }}$ Edition. Houghton Mifflin Harcourt, New York, New York, USA.

Sutherland, R.W., P.R. Dunning, and W.M. Baker. 2010. Amphibian encounter rates on roads with different amounts of traffic and urbanization. Conservation Biology 24:1626-1635.

Sutton, W.B., K. Barrett, A.T. Moody, C.S. Loftin, P.G. deMaynadier, and P. Nanjappa. 2015. Predicted changes in climatic niche and climate refugia of conservation priority salamander species in the northeastern United States. Forests 6:1-26

Taylor, J. 1984. Comparative Evidence for Competition between the Salamanders Ambystoma gracile and Taricha granulosa. Copeia 1984:672-683.

Thomson, R.C., A.N. Wright, and H.B. Shaffer. 2016. California amphibian and reptile species of special concern. University of California Press, Oakland, California, USA.

Townsend, J.M., and C.T. Driscoll. 2013. Red-backed Salamander (Plethodon cinereus) as a bioindicator of mercury in terrestrial forests of the northeastern United States. Ecological Indicators 34:168-171.

Trenham, P.C. 2001. Terrestrial habitat use by adult California Tiger Salamanders. Journal of Herpetology 35:343-346.

Trenham, P.C., and H.B. Shaffer. 2005. Amphibian upland habitat use and its consequences for population viability. Ecological Applications 15:1158-1168.

Twitty, V.C. 1935. Two new species of Triturus from California. Copeia, 1935:73-80.

Twitty, V.C. 1937. Experiments on the phenomenon of paralysis produced by a toxin occurring in Triturus embryos. Journal of Experimental Zoology 76:67-104. 
Twitty, V.C. 1942. The Species of Californian Triturus. Copeia 1942:65-76.

Twitty, V.C. 1955. Field experiments on the biology and genetic relationships of the Californian species of Triturus. Journal of Experimental Zoology, 129:129-147

Twitty, V.C. 1966. Of Scientists and Salamanders. W.H. Freeman and Company, San Francisco, California, USA.

Twitty, V.C., D. Grant, and O. Anderson. 1964. Long distance homing in the newt Taricha rivularis. Proceedings of the National Academy of Sciences of the United States of America 51:51-58.

Twitty, V.C., Grant, D., and Anderson, O. 1966. Course and timing of the homing migration in the newt Taricha Rivularis. Proceedings of the National Academy of Sciences of the United States of America 56:864-871.

Twitty, V.C., Grant, D., and Anderson, O. 1967. Home range in relation to homing in the newt Taricha rivularis (Amphibia: Caudata). Copeia 1967:649-653.

Vaelli, P.M., K.R. Theis, J.E. Williams, L.A. O'Connell, J.A. Foster, and H.L. Eisthen. 2020. The skin microbiome facilitates adaptive tetrodotoxin production in poisonous newts. ELife 9:e53898. https://doi.org/10.7554/eLife.53898

Vestal, E.H. 1938. Biotic relations of the Woodrat (Neotoma fuscipes) in the Berkeley Hills. Journal of Mammalogy 19:1-36.

Vitt, L.J., J.P. Caldwell, H.M. Wilbur, and D.C. Smith. 1990. Amphibians as harbingers of decay. BioScience 40:418-418.

Wake, D.B. 1991. Declining amphibian populations. Science 253: 860-860.

Wake, D.B., and V.T. Vredenburg. 2008. Are we in the midst of the sixth mass extinction? A view from the world of amphibians. Proceedings of the National Academy of Sciences 105:11466-11473.

Wake, D.B., and Koo, M. S. 2018. Amphibians. Current Biology, 28:R1237-R1241.

Walls, S.C., and M.G. Williams. 2001. The effect of community composition on persistence of prey with their predators in an assemblage of pond-breeding amphibians. Oecologia 128:134-141.

Welsh, H.H., and A.J. Lind. 1996. Habitat correlates of the southern torrent salamander, Rhyacotriton variegatus (Caudata: Rhyacotritonidae), in Northwestern California. Journal of Herpetology 30:385-398. 
Welsh, H.H., and L.M. Ollivier. 1998. Stream amphibians as indicators of ecosystem stress: A case study from California's Redwoods. Ecological Applications 8:11181132.

Welsh, H.H., and S. Droege. 2001. A case for using plethodontid salamanders for monitoring biodiversity and ecosystem integrity of North American forests. Conservation Biology 15:558-569.

Wiens, J.J. 2007. Global patterns of diversification and species richness in amphibians. The American Naturalist 170:S86-106.

Williams, B., C. Hanifin, E. Brodie, and E. Brodie III, E. 2010. Tetrodotoxin affects survival probability of Rough-skinned Newts (Taricha granulosa) faced with TTXresistant garter snake predators (Thamnophis sirtalis). Chemoecology 20:285-290.

Wyman, R.L. 1998. Experimental assessment of salamanders as predators of detrital food webs: Effects on invertebrates, decomposition and the carbon cycle. Biodiversity \& Conservation 7: 641-650. 